\title{
Enhanced formation of non-phenolic androgen metabolites with intrinsic oestrogen-like gene transactivation potency in human breast cancer cells: a distinctive metabolic pattern
}

\author{
Gregorio Pérez-Palacios ${ }^{1}$, René Santillán ${ }^{1,2}$, Rocío García-Becerra ${ }^{2}$, Elizabeth Borja-Cacho ${ }^{2}$, \\ Fernando Larrea ${ }^{2}$, Pablo Damián-Matsumura ${ }^{3}$, Leticia González ${ }^{3}$ and Ana E Lemus ${ }^{3}$ \\ ${ }^{1}$ Reproductive Health Research, Training and Communication Unit, School of Medicine, Universidad Nacional Autónoma de México, Hospital General de \\ México and Instituto Nacional de Perinatología, México City, México \\ ${ }^{2}$ Department of Reproductive Biology, Instituto Nacional de Ciencias Médicas y Nutrición S. Zubirán, México City, México \\ ${ }^{3}$ Department of Reproductive Biology, Universidad Autónoma Metropolitana Iztapalapa, Av. San Rafael Atlixco 186, Colonia Vicentina, Delegación Iztapalapa, \\ México City, México \\ (Requests for offprints should be addressed to A E Lemus; Email: anaelenalemus@aol.com)
}

\begin{abstract}
Breast cancer is a sex steroid hormone-dependent malignant neoplasia. The role of oestradiol in this malignancy has been well documented; however, the involvement of androgens has remained controversial. To determine the role of nonphenolic androgen metabolites in human breast cancer, we studied the metabolism of $\left[{ }^{14} \mathrm{C}\right]$ testosterone and $\left[{ }^{14} \mathrm{C}\right]$ androstenedione in oestrogen-dependent MCF-7 cells and non-oestrogen-dependent MDA-MB 231 cells, at different substrate concentrations $(1-10 \mu \mathrm{M})$ and time periods (30 min-48 h). Cultured non-oestrogen-dependent HeLa and yeast cells served as controls. Metabolites were identified and quantified by reverse isotope dilution. A distinctive pattern of androgen metabolism was identified in MCF-7 cells, being the $5 \alpha$-androstane- $3 \alpha, 17 \beta$-diol $(3 \alpha, 5 \alpha$-diol) and its $3 \beta$ epimer $(3 \beta, 5 \alpha$-diol), the major conversion products of testosterone $(48 \cdot 3 \%)$, with $5 \alpha$-dihydrotestosterone as intermediary. The formation of $3 \alpha, 5 \alpha$-diol and $3 \beta, 5 \alpha$-diol (diols) was substrate concentration- and time-dependent, and abolished by finasteride. In contrast, very little of any diol formation was observed in MDA-MB 231, HeLa and yeast cell incubations. Additional enzyme gene expression studies revealed an overexpression of $5 \alpha$-steroid reductase type- 1 in
\end{abstract}

MCF-7 cells, as compared with MDA-MB 231 cells. The oestrogen-like activities of diols were assessed in HeLa cells co-transfected with expression vectors for $\alpha$ or $\beta$ subtypes of the human oestrogen receptor (hER) genes and for an oestrogen-responsive reporter gene. The results show that $3 \beta$, $5 \alpha$-diol and to a lesser extent $3 \alpha, 5 \alpha$-diol bind with high relative affinity to hER $\alpha$ and $h E R \beta$.

Both diols induced hER-mediated reporter gene transactivation in a dose-response manner, similar to that induced by oestradiol, though with lower potency, an effect that was abolished by ICI-182 780. Furthermore, $3 \beta, 5 \alpha$-diol and to lesser extent $3 \alpha, 5 \alpha$-diol induced MCF-7 cell proliferation. The overall results demonstrated that MCF-7 cells exhibit enhanced expression and activity of androgen-metabolising enzymes, leading to rapid and large diol formation, and provide evidence that these androgen metabolites exert a potent oestrogen-agonistic effect, at genomic level, in oestrogen-dependent breast cancer cells. The data suggest that diols may act as in situ intracrine factors in breast cancer and that its formation can be pharmacologically inhibited.

Journal of Endocrinology (2006) 190, 805-818

\section{Introduction}

The key role of oestrogens for both the initiation and progression of most breast cancer tumours has been well established (Kirschner 1979, Nicholson et al. 1988, Pike \& Spicer 1991, Pike et al. 1993, Musgrove \& Sutherland 1994, Pasqualini \& Chetrite 1996, Girdler \& Brotherick 2000); however, the precise involvement of other sex steroid hormones on this malignancy has remained a controversial issue. Evidence has accumulated indicating that androgens may act as either stimulating or inhibiting hormonal agents in breast cancer, though the mechanisms by which they exert these effects have not yet been elucidated. Indeed, numerous studies in animal models have shown that androgens, at physiological concentrations, stimulate growth in mammary cancer (Smith \& King 1972, Liao et al. 1998, Xie et al. 1999, Liao \& Dickson 2002, Somboonporn \& Davis 2004), while other reports have indicated that their administration results in tumour regression of chemically and hormone-induced breast cancers (Costlow et al. 1976, Zhou et al. 2000). The inhibitory capability of androgens in human breast cancer has been documented in experimental and clinical studies 
(Poulin et al. 1988, Jørgensen et al. 1997, Szelei et al. 1997, Adams 1998, Labrie et al. 2003, Greeve et al. 2004, Somboonporn \& Davis 2004), though the absence of anti-proliferative effects on several human breast cancer cells has also been reported (Roy et al. 1992). Interestingly, several studies have shown that androgens may exhibit an initial inhibitory effect that shift to a late stimulatory effect on human breast cancer cell proliferation (Lippman et al. 1976, Hackenberg et al. 1993, Labrie et al. 1998, Aspinall et al. 2004).

The presence of androgens in normal and malignant breast tissue, as well as their enzyme-mediated conversion to oestrogens, has been well documented in pre- and postmenopausal women (reviewed in Pasqualini \& Chetrite (1996)). Although the aromatisation of androgens in breast cancer cells has remained controversial, low, but reproducible aromatase activity has been detected in MCF-7 cells (Sonne-Hansen \& Lykkesfeldt 2005). To avoid oestrogen formation, several aromatase inhibitors have been widely used in therapeutic schemes in breast cancer (Coombes et al. 1987, Santen et al. 1990, Demers 1994, Goss 1999, Ragaz 1999, Sasano et al. 1999), although the oestrogen-like effects of androgens are not completely suppressed by this treatment (Brodie et al. 1977, Brodie \& Longcope 1980, Coombes et al. 1984, Wing et al. 1985, Lippman 1998, Buzdar 2002, Lønning 2004, Brueggemeier et al. 2005). These observations raise the important question as to whether androgens are locally bioconverted to non-phenolic metabolites with intrinsic oestrogenic activities. Androgen-metabolising enzymes, other than aromatase, have been identified and characterised in human breast cancer tissue and cells (Bonney et al. 1983, Labrie et al. 1992, 1997, 2000, Sasano et al. 1996, Gingras et al . 1999, Ariga et al. 2000, Suzuki et al. 2000), and an overexpression of $5 \alpha$-steroid reductase type- 1 gene has been reported in human breast cancer tumours (Suzuki et al. 2001).

To determine whether androgens are bioconverted to A-ring-reduced derivatives with intrinsic oestrogen-agonistic potency in breast cancer, we studied the metabolism of $\left[{ }^{14} \mathrm{C}\right]-$ labelled testosterone and $\Delta^{4} \mathrm{~A}$ in oestrogen-dependent (MCF7) and non-oestrogen-dependent (MDA-MB 231) human breast cancer cells. Non-oestrogen-dependent human uterine cervical cancer (HeLa) cells and yeast cells served as experimental controls. The results disclose a distinctive androgen-metabolic pathway in MCF-7 cells, characterised by overexpression and enhanced activities of the androgenmetabolising enzymes, resulting in a large formation of $3 \alpha, 5 \alpha$-diol and $3 \beta, 5 \alpha$-diol. In subsequent studies, the oestrogen-like activity of both the diols, was assessed by their binding affinity to the $\alpha$ and $\beta$ subtypes of the human oestrogen receptor (hER), their capability to activate oestrogen response elements of a reporter gene in the construct assay employed, and their ability to induce cell proliferation in MCF-7 cells.

Further interest for the conduction of this study stemmed from the recent observations in our laboratory (Lemus et al. 2000, 2001, Larrea et al. 2001, Santillán et al. 2001,
García-Becerra et al. 2002), demonstrating that the A-ring tetrahydro-reduced metabolites of norethisterone, levonorgestrel and gestodene, possess oestrogen-agonistic activities, suggesting that they could be involved in the activation of breast cancer cell proliferation induced by high doses of synthetic contraceptive progestins derived from 19-nor testosterone, as it has been previously reported (Catherino et al. 1993, Schoonen et al. 1995a,1995b).

\section{Materials and Methods}

Steroids and chemicals

$\left[4-{ }^{14} \mathrm{C}\right]$ Testosterone $\left(\left[{ }^{14} \mathrm{C}\right]-\mathrm{T}\right)$, specific activity (sp. act.) $45 \mathrm{mCi} / \mathrm{mmol} ;\left[{ }^{4}{ }^{14} \mathrm{C}\right]$ androstenedione $\left(\left[{ }^{14} \mathrm{C}\right]-\Delta^{4} \mathrm{~A}\right)$, sp. act. $57 \cdot 5 \mathrm{mCi} / \mathrm{mmol} ;\left[2,4,6,7,16,17-{ }^{3} \mathrm{H}\right]$ oestradiol $\left(\left[{ }^{3} \mathrm{H}\right]-\mathrm{E}_{2}\right)$, sp. act. $148 \mathrm{Ci} / \mathrm{mmol}$, [ring-3,5- ${ }^{3} \mathrm{H}$ ] chloramphenicol, sp. act. $50 \mathrm{Ci} / \mathrm{mmol}$ and $\left[{ }^{3} \mathrm{H}\right]$ thymidine, sp. act. $14 \mathrm{Ci} / \mathrm{mmol}$ were purchased from NEN Research Products (Boston, MA, USA) and non-radioactive steroids were supplied by Sigma. Cell culture media, enzymes, gene primers and reverse transcriptase (RT)-PCR kits and reagents were purchased from Invitrogen. Fetal bovine serum (FBS) was supplied by Hyclone Laboratories, Inc. (Logan, UT, USA). All reagents and solvents used were of analytical grade.

\section{Cell lines and culture}

Human breast cancer cells lines MCF-7 (hER dependent) and MDA-MB 231 (hER independent), obtained from Dr A Zentella (Instituto Nacional de Ciencias Médicas y Nutrición S. Zubirán, Mexico City, México) were cultured in T-45 flasks with phenol red Dulbecco's modified Eagle mediumhigh glucose (DMEM-HG) containing L-glutamine and supplemented with 5\% FBS, $100 \mathrm{U} / \mathrm{ml}$ penicillin, $100 \mu \mathrm{g} / \mathrm{ml}$ streptomycin and $10 \mathrm{nM}$ oestradiol, in a $95 \%$ air:5\% $\mathrm{CO}_{2}$ atmosphere, at $37^{\circ} \mathrm{C}$. Human uterine cervical cancer (HeLa) cells, kindly supplied by Dr A J Cooney (Baylor College of Medicine, Houston, TX, USA), were cultured in T-45 flasks with phenol red DMEM-HG containing L-glutamine and supplemented with $10 \%$ stripped FBS, $100 \mathrm{U} / \mathrm{ml}$ penicillin and $100 \mu \mathrm{g} / \mathrm{ml}$ streptomycin in a $95 \%$ air: $5 \% \mathrm{CO}_{2}$ atmosphere, at $37^{\circ} \mathrm{C}$. Yeast cells (Saccharomyces cerevisiae), were cultured in gold medium at $32{ }^{\circ} \mathrm{C}$ by continuous shaking using air as the gas phase.

\section{Androgen metabolism}

To assess the in situ conversion of androgens to A-ringreduced derivatives in human breast cancer, the metabolism of $\left[{ }^{14} \mathrm{C}\right]-\mathrm{T}$ and $\left[{ }^{14} \mathrm{C}\right]-\Delta^{4} \mathrm{~A}$ in MCF-7 and MDA-MB 231 cells maintained in culture was studied using $\mathrm{HeLa}$ and yeast cells as experimental controls. Incubations were done at a cell density of $2 \times 10^{6}$, at $37^{\circ} \mathrm{C}$, in a $95 \%$ air: $5 \% \mathrm{CO}_{2}$ atmosphere, using the increasing substrate concentrations $(1-10 \mu \mathrm{M})$ of either 
$\left[{ }^{14} \mathrm{C}\right]-\mathrm{T}$ or $\left[{ }^{14} \mathrm{C}\right]-\Delta^{4} \mathrm{~A}$, for different time periods (30 min$48 \mathrm{~h}$ ), at $\mathrm{pH} 7 \cdot 4$ and $5 \cdot 2$, in the absence or presence of $1 \mathrm{mM}$ finasteride (Merck). All incubations were carried out in phenol red-free and oestradiol-free, supplemented DMEMHG culture medium. To determine the activities of the two types of $5 \alpha$-steroid reductases (Russell \& Wilson 1994), incubations were carried out at $\mathrm{pH} 7 \cdot 4$ and $5 \cdot 2$. In addition, similar incubations were done using cell homogenates at $\mathrm{pH} 7 \cdot 4$ and $5 \cdot 2$, in the presence of $2 \cdot 5 \mu \mathrm{M}$ NADPH. Final incubation volume was $3 \mathrm{ml}$. Cell-free and boiled inactivated cell incubations, carried out under identical conditions, were used as negative controls. Protein content was determined by a protein-dye-binding method (Bradford 1976) using BSA as standard. At the end of the incubation period, the reaction was stopped by the addition of ethyl acetate, and radiolabelled steroids were extracted $(4 \times)$ using three volumes of watersaturated ethyl acetate. The organic extracts were partitioned between petroleum ether and $10 \%$ aqueous methanol, and $2 \cdot 5 \mu \mathrm{g}$ each of the following steroid carriers were added to the methanolic extracts: testosterone (T), 17ß-hydroxy-4androstene-3-one; $5 \alpha$-dihydrotestosterone (DHT), $17 \beta$-hydroxy- $5 \alpha$-androstane-3-one; $3 \alpha, 5 \alpha$-androstanediol

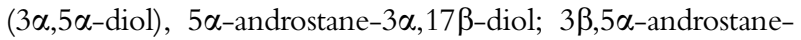
diol ( $3 \beta, 5 \alpha$-diol), $5 \alpha$-androstane- $3 \beta, 17 \beta$-diol; androstenedione $\left(\Delta^{4} \mathrm{~A}\right)$ 4-androstene-3,17-dione and $5 \alpha$-dihydroandrostanedione $(5 \alpha-\mathrm{A}), 5 \alpha$-androstane-3,17-dione. The identification and radiochemical purity of androgen metabolites were established by a reverse isotope dilution technique, which included identical behaviour to that of the steroid carriers in two different thin layer chromatographic systems (chloroform:acetone, 9:1 and benzene:ethyl acetate, 2:1) and recrystallisations to obtain a constant sp. act. Radioactive labelled $\left[{ }^{14} \mathrm{C}\right]$ metabolites were located on chromatographic plates using a Packard instant imager (Downers Grove, IL, USA). Radioactivity was otherwise determined in a Packard Tri-Carb liquid scintillation spectrometer model 1900 TR (Packard Instrument Company, Inc.), using toluene containing $4 \mathrm{~g} / 1$ 2,5-diphenyloxazole (PPO) and $100 \mathrm{mg} / \mathrm{l}$ dimethyl 1,4-bis-2-(4-methyl-5-phenyloxazolyl)-benzene as the counting solution. The counting efficiency for $\left[{ }^{14} \mathrm{C}\right]$ was $86 \%$ and $\left[{ }^{3} \mathrm{H}\right]$ was $65 \%$ and quenching was corrected in all samples by external standardisation. Nonradioactive steroid carriers were detected on chromatograms using the $p$-anisaldehyde-sulphuric/acetic acids reagent. The formation rates of the metabolic conversion products of androgens are expressed as $\mathrm{pmol} / \mathrm{mg}$ of protein per hour. The enzyme-mediated bioconversion of androgens in MCF-7, MDA-MB 231 and HeLa cells is expressed as the percent conversion of testosterone and $\Delta^{4} A$ to their non-phenolic metabolites, as a function of time.

\section{Steroid enzyme expression}

The gene expression of androgen-metabolising enzymes in MCF-7 and MDA-MB 231 cells was studied by RT-PCR. Total RNA from the cells $\left(6 \times 10^{6}\right)$ was extracted using TRIzol reagent and an aliquot $(5 \mu \mathrm{g})$ from each sample was subjected to reverse transcription using a Superscript first strand cDNA synthesis kit (Invitrogen), according to the manufacturer's protocol. Semi-quantitative PCR was performed using $2 \cdot 5 \mathrm{U}$ Platinum Taq DNA polymerase, $4 \mathrm{mM}$ $\mathrm{MgCl}_{2}, 0.4 \mathrm{mM} \mathrm{dNTPs}$ and $4 \mathrm{mM}$ of each gene-specific steroid enzyme primer, using GAPDH as an internal standard. All PCRs were done up to 30 cycles, each cycle consisting of 5 min at $94^{\circ} \mathrm{C}, 30 \mathrm{~s}$ at $52-64{ }^{\circ} \mathrm{C}$ and $7 \mathrm{~min}$ at $72{ }^{\circ} \mathrm{C}$. PCR products were electrophoresed on ethidium bromidecontaining $1 \cdot 2 \%$ agarose gels, and the bands were subjected to scanning densitometry using a gel analyzer (Kodak). Results are given as relative density (mRNA enzyme/mRNA GAPDH). Gene-specific primer sequences were as follows: human steroid $5 \alpha$-reductase type-1 (SRD5A1; NM_001047): 5'TGGGAGGAGGAAAGCCTATG (sense), $5^{\prime}$ GCCACA-CCACTCCATGATTTC (anti-sense); human steroid $5 \alpha$-reductase type-2 (SRD5A2; NM_000348): 5'CATACG-GTTTAGCTTGGGTGT (sense), $5^{\prime}$ GCTTT CCGAGATTT-GGGGTAG (anti-sense); human $3 \beta$ hydroxysteroid dehydrogenase (AKR1C1; NM_001353) $5^{\prime}$ GTAAAGCTTT-AGAGGCCAC (sense), $5^{\prime}$ CACCCAT GCTTATTATCGG (anti-sense); human $3 \alpha$-hydroxysteroid dehydrogenase (AKR1C2; NM_001354) 5'GTAAA GCTCTAGAGGCCGT (sense), $5^{\prime}$ CACCCATGGTTCTT CTCGA (anti-sense) and human GAPDH: 5'TTCGCT CTCTGCTCCTCCTG (sense), 5'ACCCGTTGACTCC GACCTTC (anti-sense).

Each PCR was run three times in duplicate according to the manufacturer's recommendations and default settings.

\section{Plasmid constructs}

The expression vectors for human $\operatorname{ER} \alpha$ and $\operatorname{ER} \beta$ genes (plasmid of the cytomegalovirus (pCMV) $)_{5}-\mathrm{hER} \alpha$ and $\mathrm{pCMV}_{5}-\mathrm{hER} \beta$ ) containing the coding sequence of $\mathrm{hER} \alpha$ and hER $\beta$ were kindly provided by Dr A J Cooney. The oestrogen responsive reporter plasmid containing a fragment of the vitellogenin A2 gene promoter (positions -331 to -87) upstream of the adenovirus E1b promoter region fused to the chloramphenicol acetyltransferase (CAT) gene (EREE1b-CAT) was constructed according to the method described by Smith et al. (1993).

\section{Transfections}

The HeLa cells were plated the day before transfections in a six-well plate at a density of $3 \times 10^{5}$ cells/well in phenol redfree DMEM-HG supplemented with 5\% stripped FBS, $100 \mathrm{U} / \mathrm{ml}$ penicillin and $100 \mu \mathrm{g} / \mathrm{ml}$ streptomycin. Cells were maintained in a $95 \%$ air: $5 \% \mathrm{CO}_{2}$ atmosphere at $37^{\circ} \mathrm{C}$. The next day, cells were visualised in a microscope to assure that the cell density was $30-50 \%$ confluent. Transfections were performed in triplicate using SuperFect (Qiagen), according to the manufacturer's protocol. Briefly, serumfree media $(100 \mu \mathrm{l})$ was aliquoted and DNA added $(1 \mu \mathrm{g}$ reporter gene plasmid and $0.025 \mu \mathrm{g}$ of either hER $\alpha$ or hER $\beta$ 
gene expression vectors) and vortexed. SuperFect reagent $(10 \mu \mathrm{l})$ was added and vortexed for additional $10 \mathrm{~s}$. Following incubation at room temperature for 5-10 min, $600 \mu \mathrm{l}$ supplemented DMEM-HG was added to each tube. The medium containing the transfection complexes was added to the cell monolayer previously rinsed with PBS. The plates were incubated for $3 \mathrm{~h}$ in a $95 \%$ air: $5 \% \mathrm{CO}_{2}$ atmosphere, at $37^{\circ} \mathrm{C}$. After incubation, the plates were rinsed with PBS and $3 \mathrm{ml}$ supplemented DMEM-HG was added to each well.

\section{Binding affinity of androgen metabolites to $h E R$}

After transfection, cells were harvested by centrifugation and washed with TEDLM buffer $(20 \mathrm{mM}$ Tris- $\mathrm{HCl}, \mathrm{pH} 7 \cdot 4$ at $4{ }^{\circ} \mathrm{C}, 1.5 \mathrm{mM}$ EDTA, $0.25 \mathrm{mM}$ dithiotreitol, $10 \mu \mathrm{g} / \mathrm{ml}$ leupeptine and $10 \mathrm{mM}$ sodium molibdate) in a ratio (w/v) 1:6. The cytosolic fraction was obtained by vortexing the cells with glass beads in TEDLM buffer followed by centrifugation at $180000 \mathrm{~g}$, for $1 \mathrm{~h}$, at $2^{\circ} \mathrm{C}$, in an SW $50 \cdot 1$ rotor (Beckman Instruments, Palo Alto, CA, USA). To assess the binding affinity of $3 \alpha, 5 \alpha$-diol and $3 \beta, 5 \alpha$-diol to hER $\alpha$ and hER $\beta$, cytosol aliquots $(0.5 \mathrm{mg}$ protein $/ \mathrm{ml})$ of the co-transfected HeLa cells were incubated with $1 \mathrm{nM}\left[{ }^{3} \mathrm{H}\right]-\mathrm{E}_{2}$ at $4{ }^{\circ} \mathrm{C}$ for $18 \mathrm{~h}$, in the absence or presence of increasing concentrations (1-1000 nM) of radioinert oestradiol, $3 \alpha, 5 \alpha$-diol and $3 \beta, 5 \alpha$-diol. Bound and free steroid fractions were separated by the addition of $800 \mu \mathrm{l}$ Dextran-coated charcoal suspension (250 mg Norit-A and $25 \mathrm{mg}$ Dextran T-70) in $100 \mathrm{ml}$ TEDLM buffer and incubated for $10 \mathrm{~min}$ at $4{ }^{\circ} \mathrm{C}$. Following centrifugation at $800 \mathrm{~g}$, at $4{ }^{\circ} \mathrm{C}$, for $15 \mathrm{~min}$, aliquots $(200 \mu \mathrm{l})$ of the supernatants were submitted to radioactive counting. Radioactive content in the aqueous samples was determined using Insta-Gel Plus (Packard, Downers Grove, IL, USA) as counting solution. The results are expressed as the relative binding affinities (RBA) and the inhibition constants $\left(K_{\mathrm{i}}\right)$ of steroid competitors, as described by Reel et al. (1979) and Cheng \& Prusoff (1973) respectively.

\section{Oestrogen-agonistic effect of androgen metabolites}

The oestrogen-agonistic actions of androgen metabolites were assessed in transiently co-transfected HeLa cells with the mammalian expression vector for $h E R \alpha$ or $h E R \beta$ genes and its cognate reporter vector ERE-E1b-CAT, using oestradiol as control. Twenty-four hours after co-transfection, cells were incubated in a complete medium containing the increasing concentrations $\left(1 \times 10^{-12}-1 \times 10^{-6} \mathrm{M}\right)$ of $3 \alpha, 5 \alpha$-diol, $3 \beta, 5 \alpha$-diol and oestradiol, using dimethyl sulfoxide as the steroid vehicle. Incubations were carried out in the absence or presence of $1 \times 10^{-7}$ M ICI-182 780 (Zeneca Farma, Mexico City, Mexico), a potent steroidal antioestrogen, in a $95 \%$ air:5\% $\mathrm{CO}_{2}$ atmosphere, for $24 \mathrm{~h}$ at $37^{\circ} \mathrm{C}$. At the end of the incubation period, cells were harvested and submitted to the liquid CAT assay as previously described (Lemus et al. 2000, García-Becerra et al. 2002). Results of the transactivation studies are expressed as the effective concentration values $\left(\mathrm{EC}_{50}\right)$ of $3 \alpha, 5 \alpha$-diol, $3 \beta, 5 \alpha$-diol and oestradiol, obtained by a non-linear regression analysis, using a scientific graphic software (Origin 6·1; OriginLab, Northampton, MA, USA).

\section{Cell proliferation studies}

The MCF-7 cells were cultured in DMEM without phenol red, containing heat-inactivated FBS (5\% v/v), $2 \mathrm{mM}$ L-glutamine, $100 \mathrm{U} / \mathrm{ml}$ penicillin and $100 \mu \mathrm{g} / \mathrm{ml}$ streptomycin. Cells were incubated in six-well plates at a density of $1 \times 10^{6}$ cell/well in a $5 \% \mathrm{CO}_{2}$ humidified incubator at $37^{\circ} \mathrm{C}$. After $24 \mathrm{~h}$, the medium was replaced with DMEM containing dextran/charcoalstripped FBS $(2 \cdot 5 \%)$ and oestradiol $\left(1 \times 10^{-9} \mathrm{M}\right)$ or $3 \alpha, 5 \alpha-$ diol or $3 \beta, 5 \alpha$-diol $\left(1 \times 10^{-7} \mathrm{M}\right)$ dissolved in ethanol and incubated for $48 \mathrm{~h}$. Cells were quantified and scored to measure proliferation rate (Lopez-Diazguerrero et al. 2006). $\left[{ }^{3} \mathrm{H}\right]-$ Thymidine $(1 \mu \mathrm{Ci})$ was added to the culture medium and incubated for additional $24 \mathrm{~h}$. Cells were washed with PBS and fixed for $15 \mathrm{~min}$ with $500 \mu \mathrm{l}$ of $95 \%$ methanol in PBS. Subsequently, cells were gently washed twice with PBS and $500 \mu \mathrm{l} 0 \cdot 2 \mathrm{M} \mathrm{NaOH}$ were added. Alkaline extracts were submitted to radioactivity counting. Results were expressed as the cell proliferation (\%) induced by diols, using oestradiol and vehicle as controls.

\section{Statistical analysis}

The comparisons of experimental groups with controls in metabolic studies were done by one-way ANOVA and statistical differences between groups were established by Student's $t$-test, using the SigmaStat statistical software (Jandel Corporation, San Rafael, CA, USA). Group differences were considered significant when $P<0 \cdot 001$ was reached (twotailed test). Variance analysis of enzyme expression and cell proliferation studies was performed using the statistical software Statistical Package for the Social Sciences (SPSS, Inc., Chicago, IL, USA) and group differences were considered significant when $P<0 \cdot 05$ was reached.

\section{Results}

\section{Androgen metabolism in MCF-7 and MDA-MB 231 cells}

After partition of the MCF-7 cells organic extracts, $96 \%$ of the incubated radioactive material was recovered in the methanolic fraction. When aliquots of methanolic extract from $\left[{ }^{14} \mathrm{C}\right]-\mathrm{T}$ incubations were submitted to thin-layer chromatography, four radioactive zones were detected, as shown in Fig. 1A. Zone $1\left(R_{\mathrm{F}}=0 \cdot 22\right)$, representing the major metabolic conversion products of $\left[{ }^{14} \mathrm{C}\right]-\mathrm{T}$, had a chromatographic behaviour identical to those of the $3 \alpha, 5 \alpha$-diol and $3 \beta, 5 \alpha-$ diol carriers. After elution, representative aliquots were separately mixed with additional radioinert $3 \alpha, 5 \alpha$-diol and $3 \beta, 5 \alpha$-diol and recrystallised to constant sp. act. (Table 1). Formation of $3 \alpha, 5 \alpha$-diol was higher than that of its $3 \beta$ isomer. Zone $2\left(R_{\mathrm{F}}=0 \cdot 34\right)$ was identified as unchanged $\left[{ }^{14} \mathrm{C}\right]-\mathrm{T}$, 


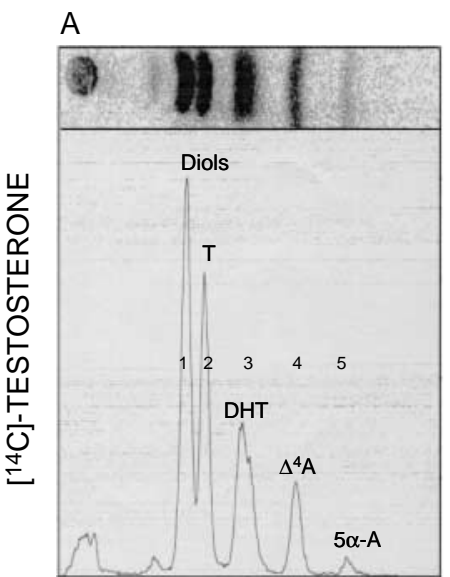

D

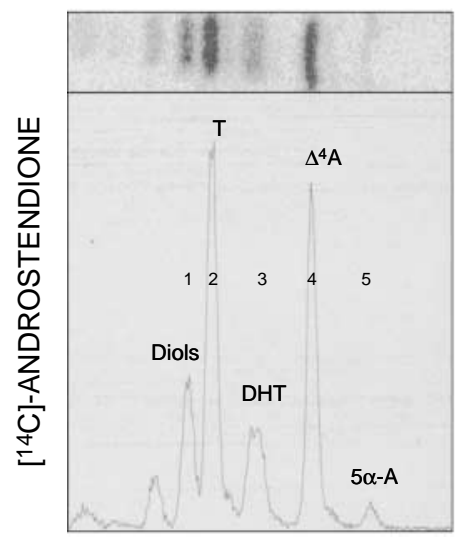

MCF-7
B

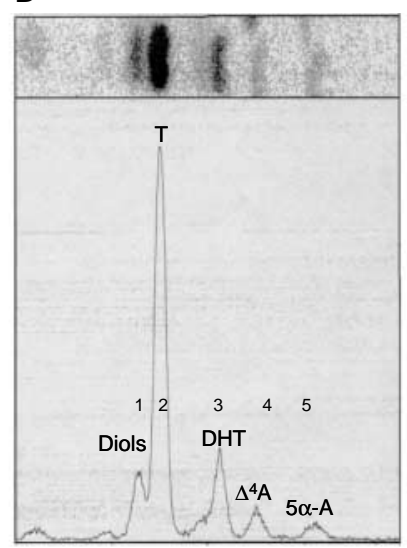

E

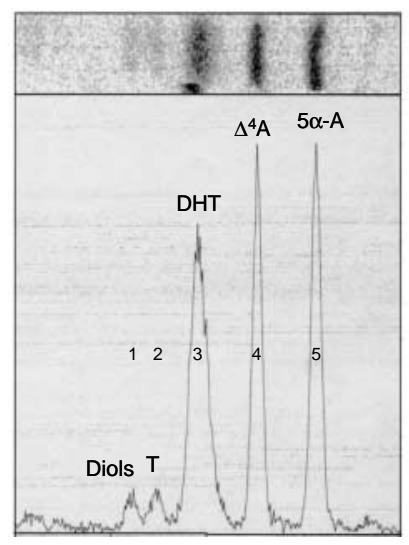

MDA-MB 231

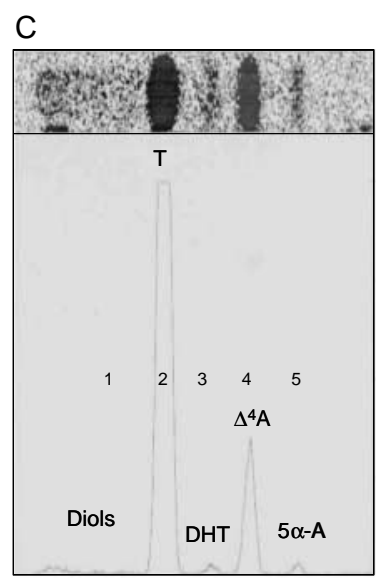

$\mathrm{F}$

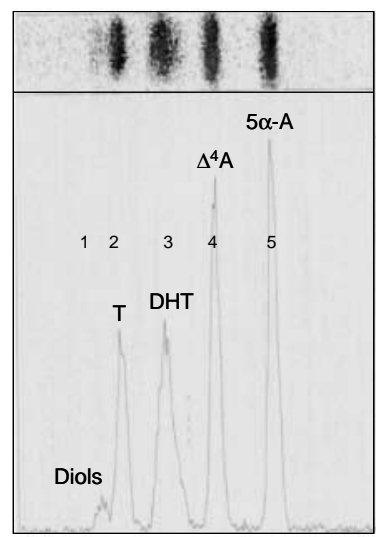

HeLa

Figure 1 Representative chromatographic profiles of the methanolic extracts of MCF-7, MDA-MB 231 and HeLa cells incubated with $2 \mu \mathrm{M}\left[{ }^{14} \mathrm{C}\right]$-labelled androgens. Extract aliquots were chromatographed on thin-layer plates. The radioactive zones detected are numbered according to their chromatographic mobility. The major metabolic conversion products of $\left[{ }^{14} \mathrm{C}\right]$ testosterone $(\mathrm{T})$ in MCF-7 cells $(\mathrm{A})$ were $3 \alpha, 5 \alpha$ - and $3 \beta, 5 \alpha-$

androstanediols (diols), while in MDA-MB 231 cells was $5 \alpha$-dihydrotestosterone (DHT) (B) and in HeLa cells (C) was androstenedione $\left(\Delta^{4} \mathrm{~A}\right) .\left[{ }^{14} \mathrm{C}\right]-\Delta^{4} \mathrm{~A}$ incubated with MCF-7 cells (D), was extensively bioconverted to testosterone and diols and to a lesser extent to DHT, whereas $\left[{ }^{14} \mathrm{C}\right]-\Delta^{4} A$ incubated with MDA-MB 231 cells (E) was extensively bioconverted to $5 \alpha-\mathrm{A}$ and $\mathrm{DHT}$. The major metabolic conversion products of $\left[{ }^{14} \mathrm{C}\right]-\Delta^{4} \mathrm{~A}$ in HeLa cells (F) were $5 \alpha-A$, testosterone and DHT. Only unchanged $\left[{ }^{14} \mathrm{C}\right]$-labelled substrates were detected in the extracts from yeast cells, cell-free and boiled inactivated cells, used as negative controls. For details see text.

while zones $3\left(R_{\mathrm{F}}=0 \cdot 46\right)$ and $4\left(R_{\mathrm{F}}=0 \cdot 55\right)$ corresponded to DHT and $\Delta^{4} A$ respectively. The radiochemical purity of these $\left[{ }^{14} \mathrm{C}\right]-\mathrm{T}$ metabolites is shown in Table 1. Chromatographic analysis of the MDA-MB 231 cells methanolic extracts revealed a completely different $\left[{ }^{14} \mathrm{C}\right]-\mathrm{T}$ conversion pattern (Fig. 1B), with limited conversion to DHT and diols, and very little formation of $\Delta^{4} \mathrm{~A}$. The metabolism of $\left[{ }^{14} \mathrm{C}\right]-\mathrm{T}$ in HeLa cells was characterised by large bioconversion to $\Delta^{4} \mathrm{~A}$ and limited formation of DHT and $5 \alpha$-A. No diols were detected in the HeLa cells methanolic extracts, as depicted in Fig. 1C.

Chromatographic analysis of the organic extracts from $\left[{ }^{14} \mathrm{C}\right]-\Delta^{4} \mathrm{~A}$ incubations with MCF-7 cells revealed the presence of five radioactive zones (Fig. 1D). Zone 1
$\left(R_{\mathrm{F}}=0 \cdot 22\right)$ and zone $2\left(R_{\mathrm{F}}=0 \cdot 34\right)$, representing one the major metabolic conversion products of $\left[{ }^{14} \mathrm{C}\right]-\Delta^{4} \mathrm{~A}$, were identified as diols and testosterone respectively. Their radiochemical purity is shown in Table 1 . Zone $3\left(R_{\mathrm{F}}=\right.$ $0 \cdot 46)$ had a chromatographic behaviour identical to that of DHT. Zone $5\left(R_{\mathrm{F}}=0 \cdot 67\right)$ had a chromatographic mobility corresponding to that of $5 \alpha-\mathrm{A}$ and zone $4\left(R_{\mathrm{F}}=0 \cdot 55\right)$ corresponded to unconverted $\left[{ }^{14} \mathrm{C}\right]-\Delta^{4} \mathrm{~A}$. The radiochemical purity of A-ring-reduced metabolites of $\left[{ }^{14} \mathrm{C}\right]-\Delta^{4} \mathrm{~A}$ is shown in Table 1. In contrast, the metabolic conversion pattern of $\left[{ }^{14} \mathrm{C}\right]-\Delta^{4} \mathrm{~A}$ in MDA-MB 231 cells (Fig. 1E) was completely different from that observed in MCF-7 cells. The metabolism of $\left[{ }^{14} \mathrm{C}\right]-\Delta^{4} \mathrm{~A}$ in HeLa cells was characterised by a limited 
Table 1 Representative radiochemical purity of isolated metabolites after in vitro incubations of human breast and uterine cervical cancer with $\left[{ }^{14} \mathrm{C}\right]$-labelled testosterone $(\mathrm{T})$ and androstenedione $\left(\Delta^{4} \mathrm{~A}\right)$

\section{Successive crystallizations specific activity $\left(\left[{ }^{14} \mathrm{C}\right] \mathrm{dpm} / \mathrm{mg}\right)$}

\section{Isolated metabolites from $\left[{ }^{14} \mathrm{C}\right]-\mathrm{T}$ incubations} $3 \alpha, 5 \alpha$-Androstanediol

$3 \beta, 5 \alpha$-Androstanediol

$5 \alpha$-Dihydrotestosterone

Androstenedione
797

658

597

504

385

291

214

224

741

660

697

515

981

763

525

493

Isolated metabolites from $\left[{ }^{14} \mathrm{C}\right]-\Delta^{4} \mathrm{~A}$ incubations

$5 \alpha$-Androstanedione

Testosterone
Successive crystallizations specific activity $\left(\left[{ }^{14} \mathrm{C}\right] \mathrm{dpm} / \mathrm{mg}\right)$

${ }^{\mathrm{a} C r y s t a l s}$

${ }^{\mathrm{b}}$ Mother liquors.

biotransformation to testosterone and $5 \alpha$-reduced metabolites, as depicted in Fig. 1F.

The metabolism of testosterone in MCF-7, MDA-MB 231 and HeLa cells, as a function of substrate concentration is shown in Fig. 2. Incubations were carried out at $37^{\circ} \mathrm{C}$, for $2 \mathrm{~h}$, at $\mathrm{pH} 7 \cdot 4$ and $5 \cdot 2$. The metabolic pattern of $\left[{ }^{14} \mathrm{C}\right]-\mathrm{T}$ in $\mathrm{MCF}-$ 7 cells (Fig. 2A and B) was similar in incubations carried out at both $\mathrm{pH}$ levels, with the distinctive feature of a large formation of diols, noticed even at the lowest substrate concentration. Interestingly, a significantly larger formation of diols occurred in incubations at $\mathrm{pH} 7 \cdot 4$ as compared with those at $\mathrm{pH} 5 \cdot 2$. In contrast, very little, if any, diol formation was noticed in incubations of MDA-MB 231 and HeLa cells with $\left[{ }^{14} \mathrm{C}\right]-\mathrm{T}$, even at the highest substrate concentration studied (Fig. 2CF). A large formation of $\Delta^{4} \mathrm{~A}$ at both $\mathrm{pH}$ levels was observed in HeLa cells and a limited bioconversion of testosterone to DHT. When MCF-7 cell homogenates, added with NADPH, were incubated with $\left[{ }^{14} \mathrm{C}\right]-\mathrm{T}$ for $2 \mathrm{~h}$, the percent conversion of testosterone to diols was significantly higher at $\mathrm{pH} 7 \cdot 4$ $(63 \cdot 2 \%)$, as compared with those at $\mathrm{pH} 5 \cdot 2(37 \cdot 4 \%)$.

The metabolism of $\left[{ }^{14} \mathrm{C}\right]-\Delta^{4} \mathrm{~A}$ in MCF-7, MDA-MB 231 and HeLa cells, as a function of substrate concentration, at $\mathrm{pH} 7 \cdot 4$ and $5 \cdot 2$ is shown in Fig 3 . The bioconversion pattern of $\Delta^{4} \mathrm{~A}$ in MCF-7 cells was similar in incubations carried out at both pH levels (Fig. 3A and B), and was characterised by a simultaneous large formation of testosterone and $5 \alpha$-reduced metabolites $(5 \alpha-\mathrm{A}$, diols and DHT). A moderately large formation of $5 \alpha$-reduced $\left[{ }^{14} \mathrm{C}\right]-\Delta^{4} \mathrm{~A}$ metabolite was noticed in incubations at $\mathrm{pH} 7 \cdot 4$ as compared with those at $\mathrm{pH} 5 \cdot 2$. Similar results were obtained in incubations of $\mathrm{MCF}-7$ cell homogenates with $\left[{ }^{14} \mathrm{C}\right]-\Delta^{4} \mathrm{~A}$. On the contrary, the bioconversion pattern of $\left[{ }^{14} \mathrm{C}\right]-\Delta^{4} \mathrm{~A}$ in MDA-MB 231 and
HeLa cells was characterised by very little formation of testosterone, noticed only at the highest substrate concentration used, and a relatively higher formation of $5 \alpha-\mathrm{A}$, particularly in incubations undertaken at $\mathrm{pH} 7 \cdot 4$ (Fig. 3C-F).

The enzyme-mediated formation of $5 \alpha$-reduced metabolites of testosterone in MCF-7, MDA-MB 231 and HeLa cells, as a function of time, is depicted in Fig. 4. Cells were incubated with $2 \mu \mathrm{M}\left[{ }^{14} \mathrm{C}\right]-\mathrm{T}$ at $37^{\circ} \mathrm{C}, \mathrm{pH} 7 \cdot 4$, at different time periods. The results demonstrated that radiolabelled testosterone incubated with MCF-7 cells was extensively bioconverted to diols, presumably through its prior conversion to DHT. Indeed, the maximal accumulation of DHT occurred at $30 \mathrm{~min}$ of incubation with a subsequent decline and a concomitant time-dependent increase on the formation of diols (Fig. 4A). At $48 \mathrm{~h}$ incubation, $48 \cdot 3 \%$ of the $\left[{ }^{14} \mathrm{C}\right]$-labelled testosterone was bioconverted to diols. According to recrystallisation data, the formation of $3 \alpha, 5 \alpha-$ diol and $3 \beta, 5 \alpha$-diol occurred in a ratio of $2: 1$. In sharp contrast, the absence of formation of diols was observed in incubations of MDA-MB 231 and HeLa cells with $\left[{ }^{14} \mathrm{C}\right]-\mathrm{T}$, with very small and delayed formation of DHT (Fig. 4B and C). The effect of a $5 \alpha$-steroid reductases inhibitor on the metabolism of androgens in MCF-7 cells is shown in Fig. 5. Cells were incubated with $2 \mu \mathrm{M}\left[{ }^{14} \mathrm{C}\right]-\mathrm{T}$ or $\left[{ }^{14} \mathrm{C}\right]-\Delta^{4} \mathrm{~A}$, at $37^{\circ} \mathrm{C}$, for $48 \mathrm{~h}$, at $\mathrm{pH} 7 \cdot 4$, in the absence or presence of $1 \mathrm{mM}$ finasteride. As it can be seen, the addition of finasteride resulted in a significant diminution of the bioconversion of radiolabelled testosterone and $\Delta^{4} A$ to their corresponding $5 \alpha$ dihydro metabolites and in an abolishment of diols formation (Fig. 5, inserts). In all incubations with MCF-7, MDA-MB 231 and HeLa cells, neither oestradiol nor oestrone was detected as conversion products of $\left[{ }^{14} \mathrm{C}\right]-\mathrm{T}$ and $\left[{ }^{14} \mathrm{C}\right]-\Delta^{4} \mathrm{~A}$. 


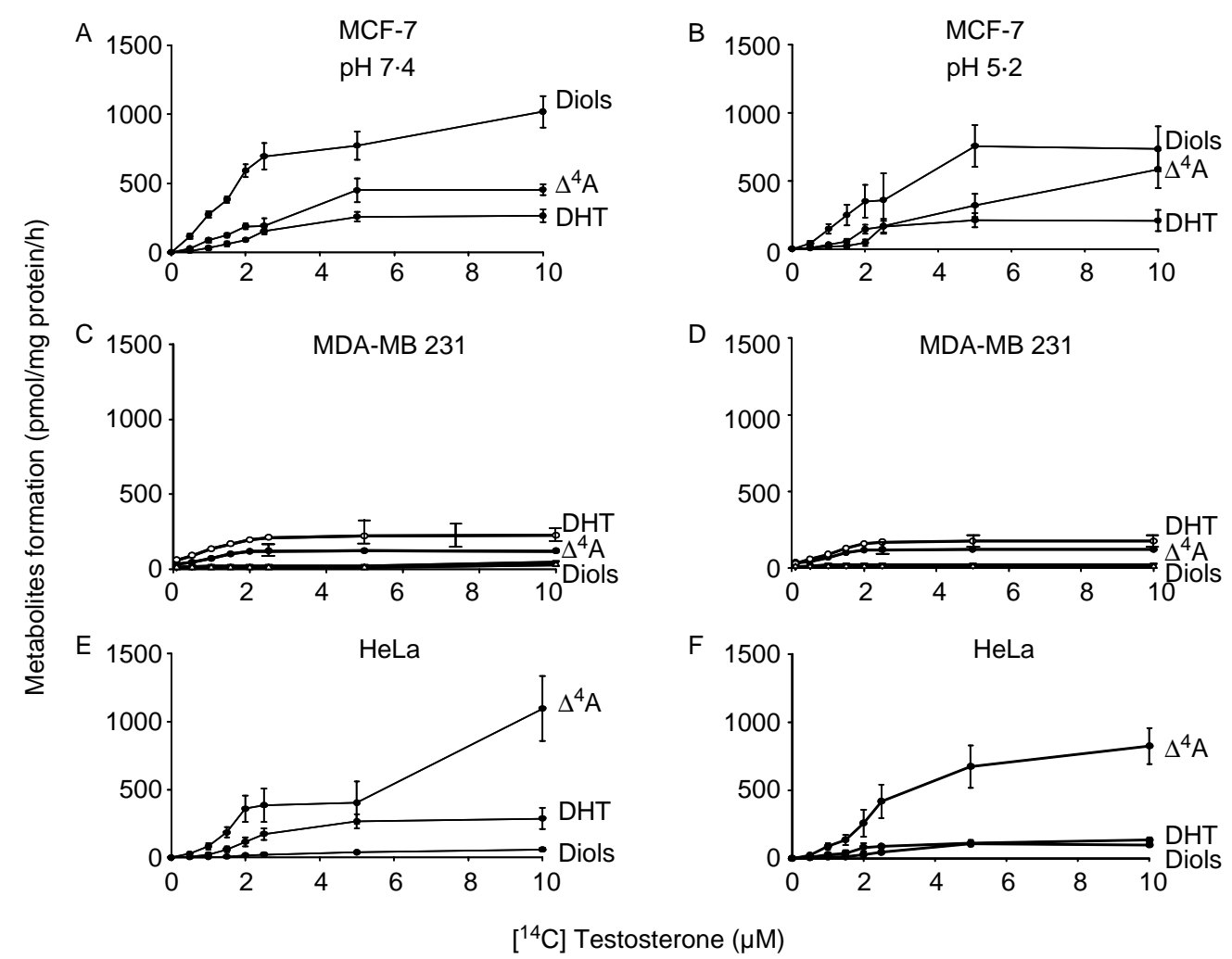

Figure 2 Bioconversion of $\left[{ }^{14} \mathrm{C}\right]$ testosterone to non-phenolic metabolites in MCF-7, MDA-MB 231 and HeLa cells, as a function of substrate concentration. Incubations were carried out for $2 \mathrm{~h}$ at $37^{\circ} \mathrm{C}$, using increasing substrate concentrations, at two different $\mathrm{pH}$ levels. The $3 \alpha, 5 \alpha$ - and $3 \beta, 5 \alpha$-androstanediols (diols) were identified as the major metabolic conversion products in MCF-7 cells, even the lowest substrate concentration. Diol formation was higher in incubations at $\mathrm{pH} 7 \cdot 4(\mathrm{~A})$, as compared with those at $\mathrm{pH} 5 \cdot 2$ (B). Androstenedione $\left(\Delta^{4} \mathrm{~A}\right)$ and $5 \alpha$-dihydrotestosterone (DHT), in a smaller proportion, were also identified as testosterone metabolites at both $\mathrm{pH}$ levels (A) and (B). On the contrary, very little formation of metabolites occurred in incubations of $\left[{ }^{14} \mathrm{C}\right]$-testosterone with MDA-MB 231 cells $(\mathrm{C})$ and (D), whereas a large bioconversion of $\left[{ }^{14} \mathrm{C}\right]$-testosterone to $\Delta^{4} \mathrm{~A}$ was observed in HeLa cells incubations, at both pH levels (E) and (F). Each point represents the mean \pm S.E.M. of five experiments in triplicate.

Only unmodified $\left[{ }^{14} \mathrm{C}\right]$-labelled substrates were identified in incubations using yeast cells, boiled inactivated cells and cellfree preparations, used as negative controls.

Enzymes gene expression profile in $M C F-7$ and $M D A-M B$ 231 cells

The results from androgen-metabolising enzymes gene expression in the two cell lines studied, as determined by semi-quantitative RT-PCR assays, are shown in Fig. 6. The level of expression of SRD5A1 was significantly $(P<0 \cdot 05)$ higher in MCF-7 cells, as compared with MDA-MB 231 cells. In contrast, the expression of SRD5A2 in both cell lines did not exhibit differences. Interestingly, the expression of SRD5A1 was significantly higher $(P<0 \cdot 01)$ in both cell lines, as compared with SRD5A2. The expression level of AKR1C1 and AKR1C2 was similar in MCF-7 and MDA-MB 231 cells, though the expression of AKR1C1 was significantly higher $(P<0 \cdot 001)$ than that of AKR1C2 in both cell lines studied.

\section{Binding affinity of androstanediols to $h E R$}

The effect of increasing concentrations of non-radioactive diols upon the $\left[{ }^{3} \mathrm{H}\right]-\mathrm{E}_{2}$ binding to hER in HeLa cells transfected with expression vectors for either hER $\alpha$ or hER $\beta$ is shown in Fig. 7. The $\left[{ }^{3} \mathrm{H}\right]-\mathrm{E}_{2}$ bound to hER in the absence of steroid competitors was set at $100 \%$ in this radioligand competitive assay. Even though both diols were competitors for $\mathrm{hER} \alpha$, the $3 \beta, 5 \alpha$-diol exhibited higher affinity (RBA $=$ $\left.1.9 \% ; K_{\mathrm{i}}=3 \cdot 25 \mathrm{nM}\right)$ than its $3 \alpha$-isomer $(\mathrm{RBA}=0 \cdot 009 \%$; $\left.K_{\mathrm{i}}=625 \mathrm{nM}\right)$. The $3 \beta, 5 \alpha$-diol was more efficient competitor for the $\beta$ subtype of hER (RBA $=0.92 \% ; K_{\mathrm{i}}=6.5 \mathrm{nM}$ ) than $3 \alpha, 5 \alpha$-diol $\left(\mathrm{RBA}=0 \cdot 006 \% ; K_{\mathrm{i}}=950 \mathrm{nM}\right)$. The $3 \beta, 5 \alpha$-diol and to a lesser extent its $3 \alpha$-isomer, bound to both subtypes 


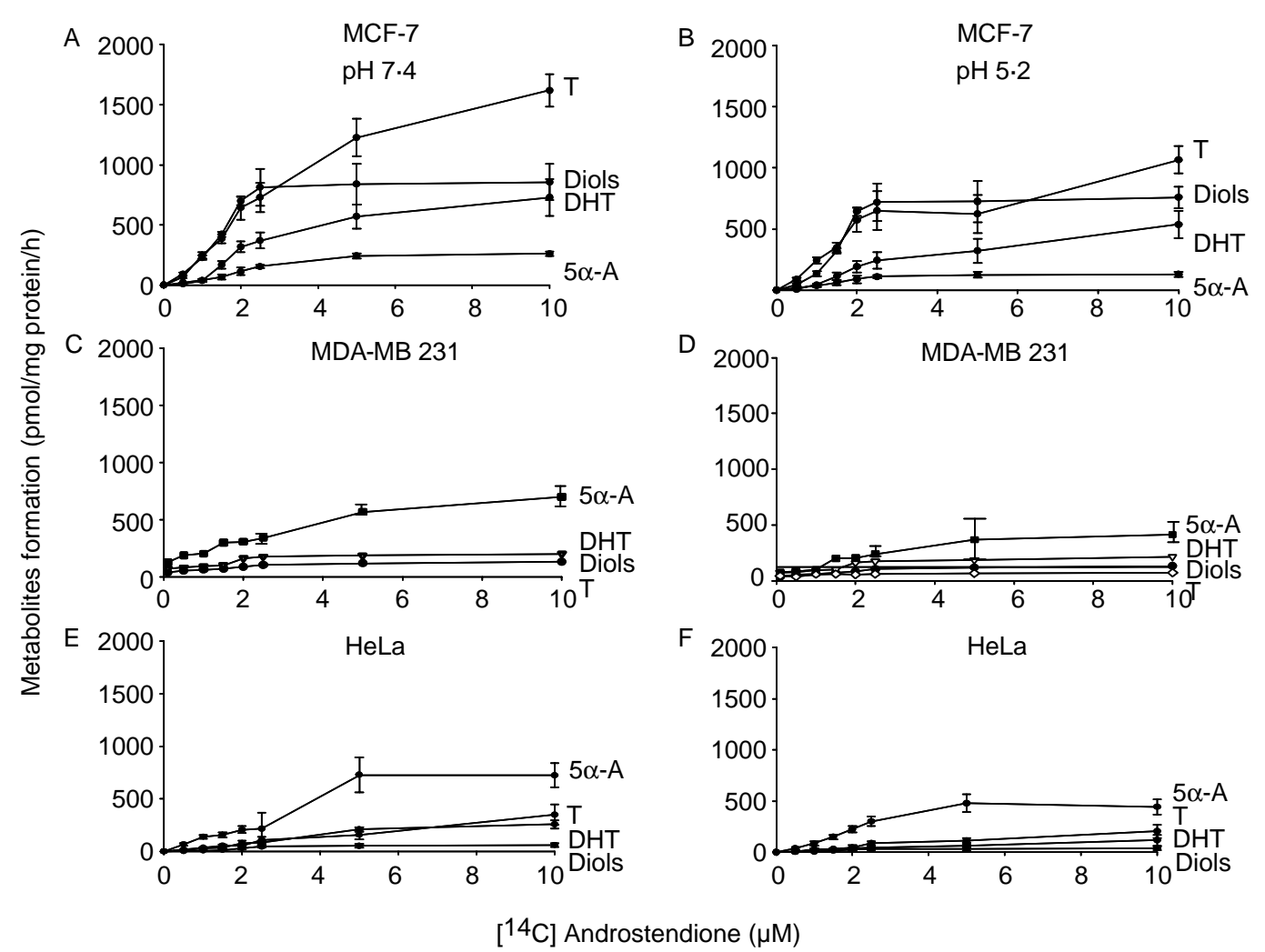

Figure 3 Bioconversion of $\left[{ }^{14} \mathrm{C}\right]$-labelled androstenedione $\left(\Delta^{4} \mathrm{~A}\right)$ to non-phenolic metabolites in MCF-7, MDA-MB 231 and HeLa cells, as a function of substrate concentration. Incubations were carried out for $2 \mathrm{~h}$ at $37^{\circ} \mathrm{C}$, using increasing substrate concentrations, at two different $\mathrm{pH}$ levels. Testosterone (T) and $3 \alpha, 5 \alpha$ - and $3 \beta, 5 \alpha$-androstanediols (diols) were identified as the major metabolic conversion products in MCF-7 cells (A) and (B). A larger formation of T and $5 \alpha$-reduced $\Delta^{4} \mathrm{~A}$ metabolites occurred at $\mathrm{pH} 7 \cdot 4(\mathrm{~A})$, as compared with incubations at pH 5.2 (B). The major metabolic product of $\left[{ }^{14} \mathrm{C}\right]-\Delta^{4} \mathrm{~A}$ in MDA-MB 231 and HeLa cells $(\mathrm{C}-\mathrm{F})$ was $5 \alpha$-dihydroandrostanedione $(5 \alpha-\mathrm{A})$ with very little formation of T and DHT. Each point represents the mean \pm S.E.M. of five experiments in triplicate.

of hER, in a similar manner to that of oestradiol used as positive control, though with lower affinity.

\section{Oestrogen-like transactivation effect of androstanediols}

The transactivation effect of $3 \alpha, 5 \alpha$-diol and its $3 \beta$-isomer in the co-transfected cell expression system employed is shown in Fig. 8. Both diols induced the transactivation of hER $\alpha-$ mediated CAT activity, in a dose-response manner, similar to that induced by oestradiol, yet with lower potency (Fig. 8A and $\mathrm{B})$. At steroid concentrations that induced the highest CAT gene transactivation, the oestrogen-like effect of $3 \beta, 5 \alpha-$ diol $\left(1 \times 10^{-7} \mathrm{M}\right)$ was 100 -fold less potent than oestradiol $\left(1 \times 10^{-9} \mathrm{M}\right)$, whereas $3 \alpha, 5 \alpha$-diol $\left(1 \times 10^{-6} \mathrm{M}\right)$ was tenfold less potent than $3 \beta, 5 \alpha$-diol as depicted in Fig. $8 \mathrm{~A}$ and $\mathrm{B}$. The effect of both diols on hER $\beta$-mediated reporter gene transcription, as compared to that of oestradiol, is shown in Fig. $8 \mathrm{C}$ and $\mathrm{D}$. The highest oestrogen-agonistic transactivation effect of $3 \beta, 5 \alpha$-diol $\left(1 \times 10^{-7} \mathrm{M}\right)$ was 100 -fold less potent than oestradiol $\left(1 \times 10^{-9} \mathrm{M}\right)$, while $3 \alpha, 5 \alpha$-diol induced transactivation only at the highest concentration employed $\left(1 \times 10^{-6} \mathrm{M}\right)$. The comparative potencies of both diols and oestradiol, to induce CAT gene transactivation mediated by the subtypes $\alpha$ and $\beta$ of hER, as judged by their $\mathrm{EC}_{50}$, are depicted in Table 2.

The addition of ICI-182 780 to cell culture incubations, significantly inhibited $(P<0 \cdot 001)$ the ability of $3 \beta, 5 \alpha$-diol, $3 \alpha, 5 \alpha$-diol and oestradiol to stimulate hER $\alpha-$ and hER $\beta$ mediated transcriptional activities as shown in Fig. 9. These results ensured the stimulatory activity of diols via both subtypes of hER.

\section{Effect of diols in cell proliferation}

To assess the effect of $3 \alpha, 5 \alpha$ - and $3 \beta, 5 \alpha$-diols on cell proliferation in MCF-7 cells, a set of experiments using [ $\left.{ }^{3} \mathrm{H}\right]-$ thymidine incorporation method was undertaken in triplicate. Oestradiol and vehicle served as experimental controls. The results indicated that after $48 \mathrm{~h}$ treatment, $3 \beta, 5 \alpha$-diol $\left(1 \times 10^{-7} \mathrm{M}\right)$ was capable of increasing the proliferation rate 

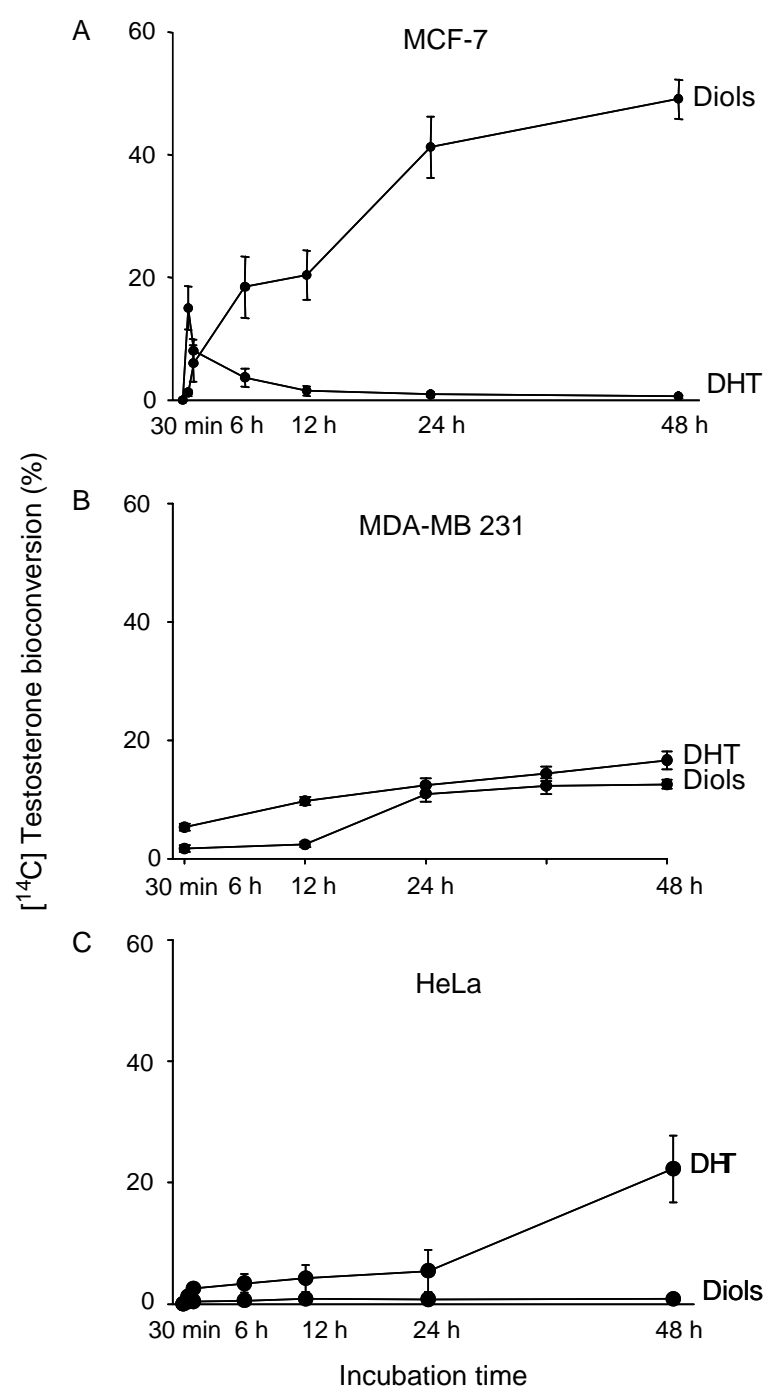

Figure 4 Formation of $5 \alpha$-reduced testosterone metabolites in MCF7, MDA-MB 231 and HeLa cells, as a function of time. Incubations were carried out using $2 \mu \mathrm{M}\left[{ }^{14} \mathrm{C}\right]$ testosterone, at $37^{\circ} \mathrm{C}, \mathrm{pH} 7 \cdot 4$, for different time periods. An early (30 min) bioconversion of testosterone to $5 \alpha$-dihydrotestosterone (DHT) and a subsequent large formation of $3 \alpha, 5 \alpha$ - and $3 \beta, 5 \alpha$-androstanediols (diols) were observed in MCF-7 cells (A). After $48 \mathrm{~h}$ incubation, $48 \cdot 3 \%$ of the radiolabelled substrate was bioconverted to diols. A limited formation of diols was observed in MDA-MB 231 cells incubations (B), while a delayed formation of DHT without further conversion to diols occurred in HeLa cells incubations (C). Each point represents the mean \pm S.E.M. in five experiments in triplicate.

in MCF-7 cells significantly (150\%) as compared with vehicle, in a similar fashion to that exerted by $1 \times 10^{-9} \mathrm{M}$ oestradiol $(140 \%)$. Treatment with $1 \times 10^{-7} \mathrm{M} 3 \alpha, 5 \alpha$-diol also increased cell proliferation (50\%) as compared with vehicle in MCF-7 cells. The effect of oestradiol, $3 \alpha, 5 \alpha-$ and $3 \beta, 5 \alpha-$ diols on MCF-7 cell proliferation was not seen in MDA-MB 231 cells.

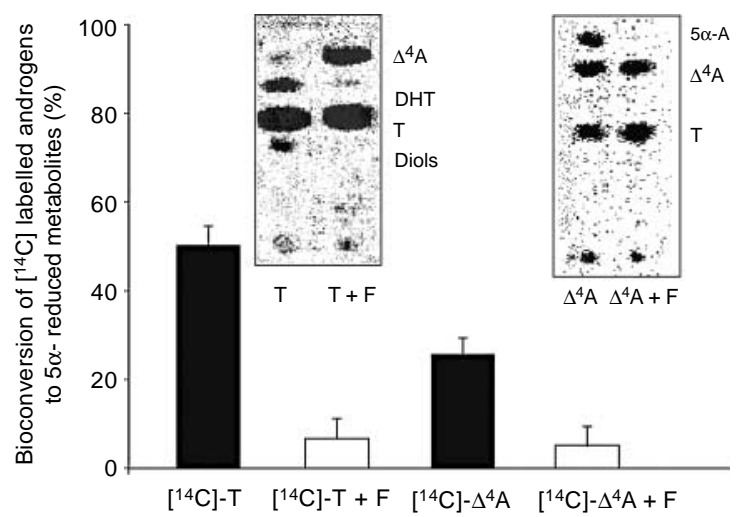

Figure 5 Effects of finasteride $(\mathrm{F})$, a $5 \alpha$-steroid reductases inhibitor, on androgen metabolism in MCF-7 cells. Incubations were carried out with $2 \mu \mathrm{M}\left[{ }^{14} \mathrm{C}\right]$ testosterone $\left(\left[{ }^{14} \mathrm{C}\right]-\mathrm{T}\right)$ or $2 \mu \mathrm{M}\left[{ }^{14} \mathrm{C}\right]$ androstenedione $\left(\left[{ }^{14} \mathrm{C}\right]-\Delta^{4} \mathrm{~A}\right)$, at $37^{\circ} \mathrm{C}, \mathrm{pH} 7 \cdot 4$, for $48 \mathrm{~h}$, in the presence or absence of $1 \mathrm{mM}$ finasteride. Addition of the enzyme inhibitor diminished the formation of $5 \alpha$-dihydrotestosterone (DHT) or $5 \alpha$-androstanedione ( $5 \alpha-A)$ and precluded the formation of androstanediols (diols). The data represent the mean \pm s.E.M. of five experiments in triplicate. Location of radiolabelled steroids in chromatographic plates is shown in the inserts.

\section{Discussion}

The results of this study clearly demonstrate that oestrogendependent human breast cancer cells efficiently biotransform androgens to A-ring tetrahydro-reduced metabolites, which possess the capability to transactivate oestrogen-regulated genes mediated by the $\alpha$ and $\beta$ subtypes of hER. Indeed, MCF-7 cells incubated with radiolabelled androgens exhibited a large and rapid formation of tetrahydro-reduced metabolites, thus indicating a great activity of $5 \alpha$-steroid reductases, types 1 and 2 , and two enzymes of the aldo-keto reductases family, the $3 \alpha-$ hydroxysteroid dehydrogenase and the $3 \beta$-hydroxysteroid dehydrogenase. The large conversion of testosterone to $3 \alpha, 5 \alpha$ - and $3 \beta, 5 \alpha$-diols in MCF-7 cells had DHT as an obligatory intermediary as it was demonstrated by its inhibition induced by finasteride. This observation supports the concept that formation of diols from testosterone requires enzymemediated $5 \alpha$-reduction (trans $\mathrm{A} / \mathrm{B}$ ring junction) as the first metabolic step. In contrast, non-oestrogen-dependent MDAMB 231 cells exhibited a limited bioconversion of androgens to $5 \alpha$-reduced metabolites and very little, if any, formation of diols. An absence of bioconversion of androgen to diols was observed in HeLa and yeast cell incubations used as controls. The finding of an enhanced enzyme $5 \alpha$-steroid reductase activity in MCF-7 cells, particularly in experiments carried out at $\mathrm{pH} 7 \cdot 4$, is in line with the report of Suzuki et al. (2001), who have demonstrated an overexpression of the $5 \alpha$-steroid reductase type- 1 gene in human breast cancer tissues. Interestingly, our results revealed a selectively higher expression level of SRD5A1 in MCF-7 cells as compared with MDA-MB 231 cells, indicating a good agreement between enzyme expression levels and activities in human breast cancer cells. In contrast, no difference on the 
A

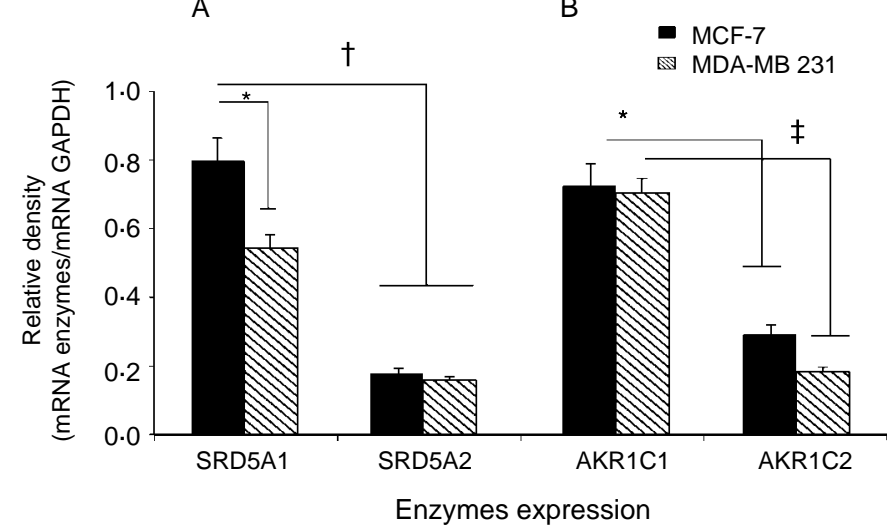

Figure $65 \alpha$-Steroid reductases type-1 (SRD5A1) and type-2 (SRD5A2), $3 \beta$ hydroxysteroid dehydrogenase (AKR1C1) and $3 \alpha$-hydroxysteroid dehydrogenase (AKR1C2) mRNA expression levels in MCF-7 and MDAMB 231 cells. The expression of SRD5A1-mRNA is significantly higher in MCF-7 cells (1 45 -fold) as compared with those of MDA-MB 231. No differences were observed in the SRD5A2 expression levels in both cell lines. Interestingly, the mRNA expression of SRD5A1 in MCF-7 and MDAMB 231 cells were significantly higher than that of SRD5A2 expression (4-4- and 3·4-fold respectively). The AKR1C1 expression levels in MCF-7 and MDA-MB 231 cells did not exhibit significant differences, while the mRNA expression of AKR1C2 was higher in MCF-7 as compared with MDA-MB 231 cells. The expression of AKR1C1 in MCF-7 and MDA-MB 231 cells was significantly higher than that of AKR1C2 (2 4 - and 3·6-fold respectively). Values are given as relative density ratios. The data represent the mean \pm S.D. of four experiments performed in duplicate. $* P<0 \cdot 05,{ }^{\dagger} P<$ $0 \cdot 01,{ }^{\ddagger} P<0 \cdot 001$. expression levels of AKR1C1 and AKR1C2 in MCF-7 and MDA-MB 231 cells was noticed. These results confirm and extend the report of Wiebe et al. (2000), who, using radiolabelled progesterone as substrate, demonstrated an enhanced $5 \alpha$-steroid reductase activity and also an overexpression of the $5 \alpha$-steroid reductase type-1 gene in MCF-7 cells, as compared with oestrogen-resistant breast cells (MCF10A). Furthermore, Wiebe \& Lewis (2003) demonstrated the
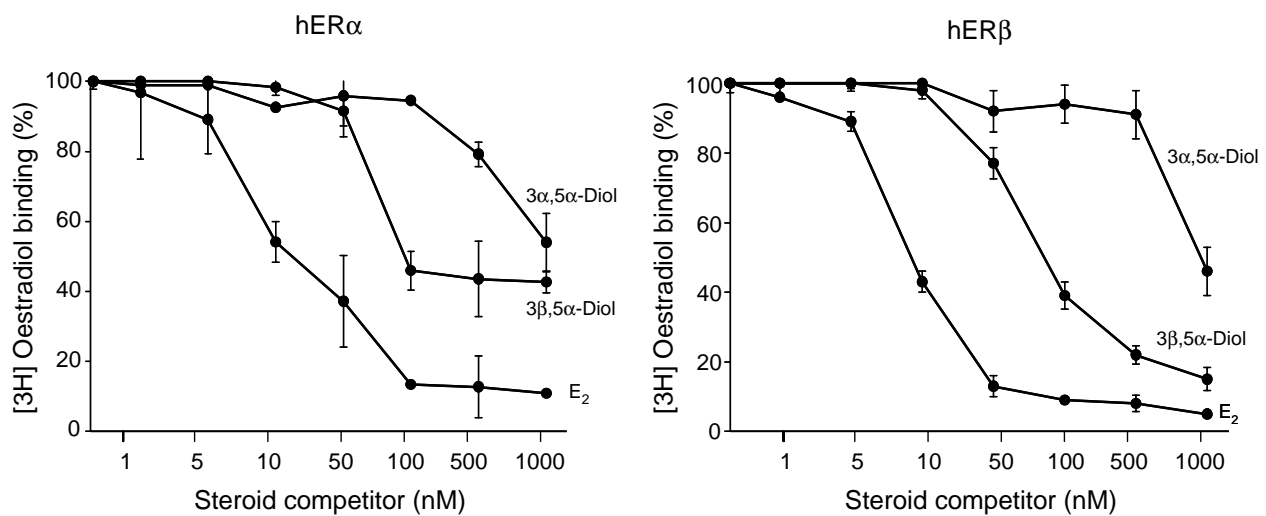

Figure 7 Binding affinities of $3 \alpha, 5 \alpha$ - and $3 \beta, 5 \alpha$-androstanediols (diols) to human oestrogen receptors (hER). Cytosol aliquots of HeLa cells transfected with either $\mathrm{hER} \alpha$ or $\mathrm{hER} \beta$ gene expression vectors were incubated with $1 \mathrm{nM}\left[{ }^{3} \mathrm{H}\right]$ oestradiol at $4{ }^{\circ} \mathrm{C}$, for $48 \mathrm{~h}$, in the absence or presence of increasing concentrations of radioinert $3 \alpha, 5 \alpha$-diol, $3 \beta, 5 \alpha$-diol and oestradiol $\left(E_{2}\right)$. Bound and free steroid fractions were separated by the addition of dextran-coated charcoal. The $3 \beta, 5 \alpha$-diol efficiently bound to both subtypes of hER, though with higher affinity for $h E R \alpha$. The $3 \alpha, 5 \alpha$-diol also bound to $h E R \alpha$ and $h E R \beta$, but only at the highest concentration used. $E_{2}$, used as the control, was the most potent competitor for $\alpha$ and $\beta$ subtypes of hER. Results represent the mean \pm s.D. of five experiments in triplicate. 


\section{$\mathrm{hER} \alpha$}

A

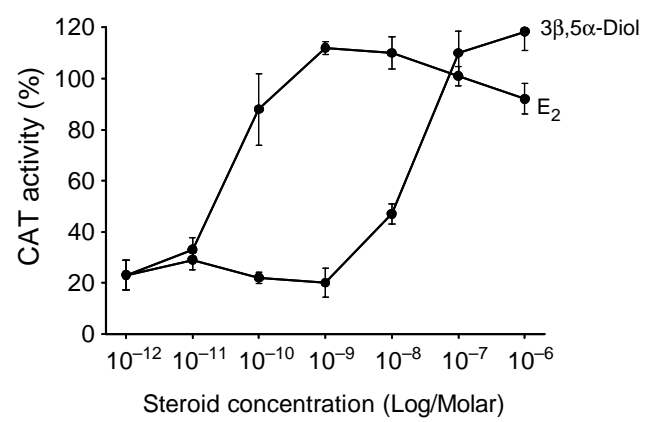

C

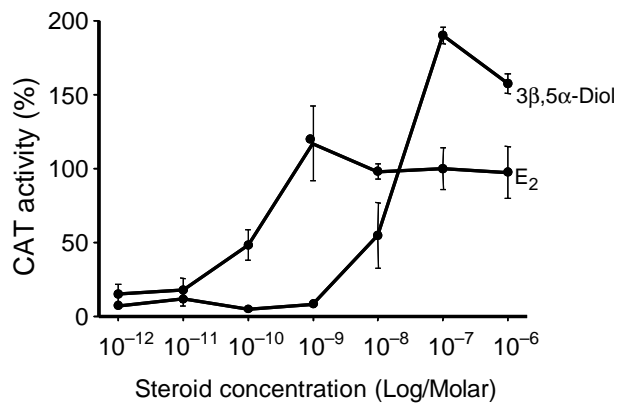

B

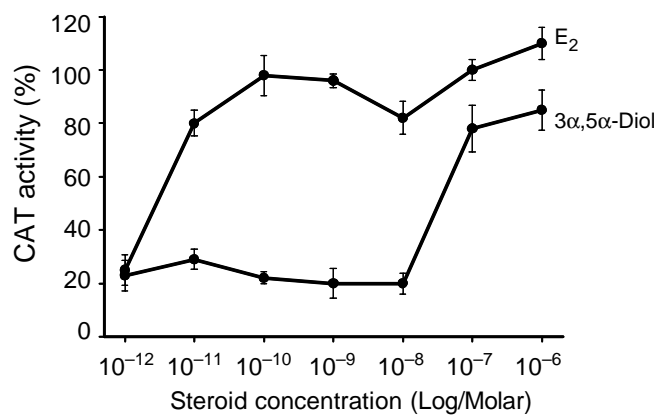

hER $\beta$

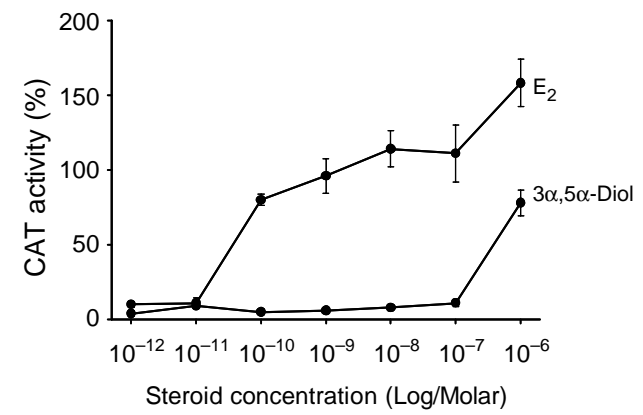

Figure 8 Oestrogen-like transactivation effects of androstanediols. Increasing concentrations of $3 \alpha, 5 \alpha$-androstanediol ( $3 \alpha, 5 \alpha$-diol), $3 \beta, 5 \alpha$-androstanediol $\left(3 \beta, 5 \alpha\right.$-diol) and oestradiol $\left(E_{2}\right)$ were incubated with HeLa cells transiently co-transfected with expression vectors for $h E R \alpha$ or $h E R \beta$ and an ERE-E1b-CAT reporter gene, for $24 \mathrm{~h}$, at $37^{\circ} \mathrm{C}$. Results are expressed as percentage of CAT activity. Concentrations of $1 \times 10^{-8} \mathrm{M}$ onwards of $3 \beta, 5 \alpha$-Diol efficiently induced $h E R \alpha$ - and $h E R \beta$-mediated transactivation, in a similar manner to that of $E_{2}(A)$ and $(C) .3 \alpha, 5 \alpha$-diol also induced $h E R \alpha$ and hER $\beta$-mediated transactivation, yet with lower potency (B) and (D). Values are the mean \pm s.D. of five experiments performed in triplicate. For details see text.

lower expression levels of $3 \alpha$ - and $3 \beta$-hydroxysteroid dehydrogenase genes in breast cancer tissues as compared with paired breast normal tissue.

Another striking finding of this study was that $3 \alpha, 5 \alpha$ - and $3 \beta, 5 \alpha$-diols, the major metabolic conversion products of testosterone in MCF-7 cells, interact with relatively high binding affinity with both subtypes of hER and are capable of transactivating an oestrogen-dependent reporter gene (CAT) in the transiently co-transfected cell expression system employed, resembling the effects of naturally occurring oestradiol, though with lower potency. It must be underlined than even the formation of $3 \alpha, 5 \alpha$-diol from testosterone was almost double than that of its $3 \beta$-epimer, according to recrystallisation data, the $3 \beta, 5 \alpha$-diol exhibited higher hERbinding affinity and higher oestrogen-like transactivation potency, as compared with its $3 \alpha$-epimer, as shown in Fig. 8 and Table 2. Further evidence that diols-induced gene transactivation in the construct assay is mediated via hRE $\alpha$ and $\operatorname{hER} \beta$, was derived from the observation that ICI-182 780 was able to preclude this effect. Our results confirm and extend previous reports on the activation of

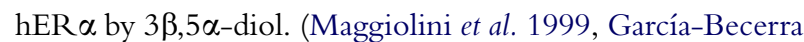
et al. 2002). These data are similar, though non-identical, with our previous observations with the tetrahydro-reduced metabolites of synthetic 19-nor progestins, which are also able to transactivate oestrogen-dependent genes mediated through $\mathrm{hER} \alpha$, but not through $\mathrm{hER} \beta$, behaving as selective hER modulators (Lemus et al. 2000, Larrea et al. 2001,

Table 2 Human oestrogen receptors (hER)-mediated gene transactivation induced by androstanediols in a co-transfected cell expression system

\begin{tabular}{|c|c|}
\hline $\mathrm{hER} \alpha(\mathrm{mol} / \mathrm{l})$ & $\mathrm{hER} \beta(\mathrm{mol} / \mathrm{l})$ \\
\hline $6 \cdot 74 \times 10^{-11}$ & $3 \cdot 37 \times 10^{-12}$ \\
\hline $1.61 \times 10^{-9}$ & $1.41 \times 10^{-8}$ \\
\hline $9 \cdot 10 \times 10^{-8}$ & $3 \cdot 05 \times 10^{-6}$ \\
\hline
\end{tabular}

Oestradiol served as control. Results are presented as the effective concentration values $\left(\mathrm{EC}_{50}\right)$. For details see text.

Journal of Endocrinology (2006) 190, 805-818

\section{Steroids}

Oestradiol

$3 \beta, 5 \alpha$-Androstanediol

$3 \alpha, 5 \alpha$-Androstanediol 

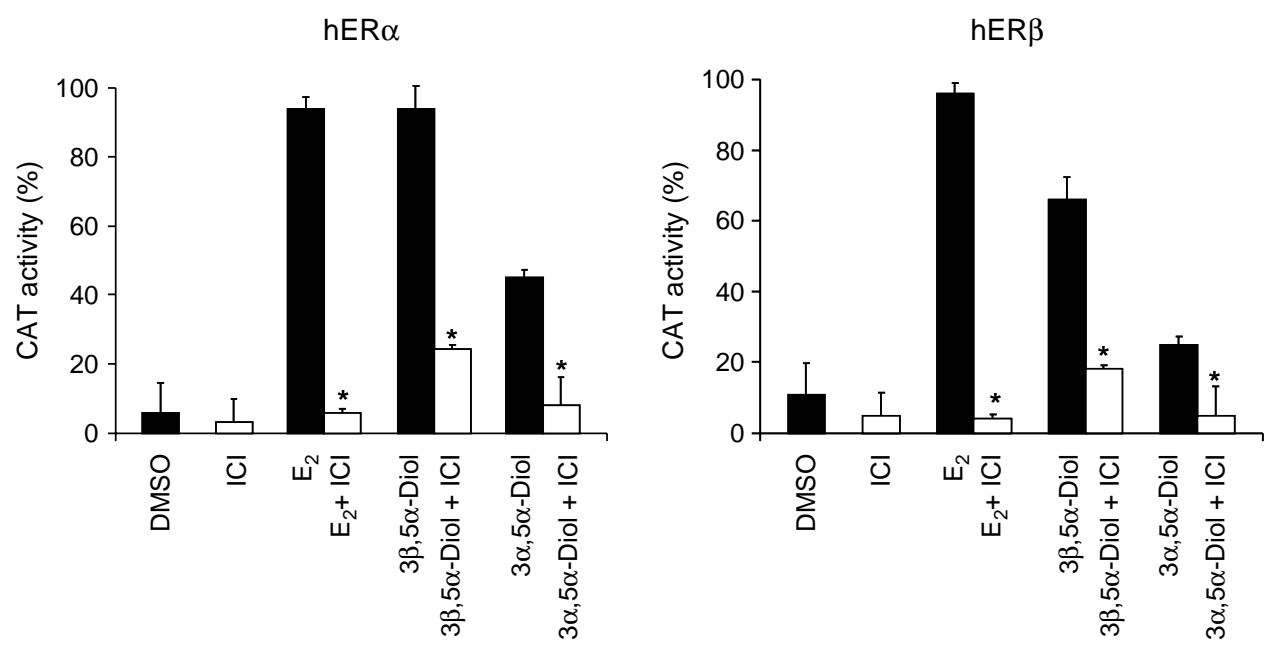

Figure 9 Effect of the antioestrogen ICl-182780 on hER-mediated transactivation induced by androstanediols. HeLa cells transiently co-transfected with expression vectors for hER $\alpha$ or hER $\beta$ and an ERE-E1b-CAT reporter gene were incubated with $1 \times 10^{-7} \mathrm{M} 3 \beta, 5 \alpha$-androstanediol $(3 \beta, 5 \alpha$-diol), $3 \alpha, 5 \alpha$ androstanediol $(3 \alpha, 5 \alpha$-diol $)$ and $1 \times 10^{-8} \mathrm{M}$ oestradiol $\left(E_{2}\right)$, in the presence or absence of $1 \times 10^{-7} \mathrm{M} \mathrm{ICl}$ $182780(\mathrm{ICl})$. Incubations with ICl alone and with steroid vehicle (DMSO) served as controls. Results are expressed as percentage of CAT activity. Addition of the antioestrogen significantly inhibited $(P<0 \cdot 001)$ the transactivation induced by androstanediols and $E_{2}$. Values are the mean \pm S.D. of five experiments performed in triplicate. ${ }^{*} P<0 \cdot 001$ vs DMSO. For details see text.

García-Becerra et al. 2002). Even though the different structural characteristics for the $\alpha$ and $\beta$ subtypes of hER displayed by the tetrahydro metabolites of naturally occurring androgens and those of 19-nor progestins have been studied (Kubli-Garfias et al. 1998, 2002), the understanding of their binding mechanisms still awaits further studies.

The study of enzyme gene expression disclosed that the large formation of diols in MCF-7 cells, with potent intrinsic oestrogen-agonistic effects at the genomic level, is the result of enhanced local activities of $5 \alpha$-steroid reductases. This is mainly due to an overexpression of SRD5A1 and may have an important physiopathological significance, since these locally produced androgen metabolites are exerting their oestrogenlike intracrine effects in the same cells in which their synthesis take place, without significant diffusion into the circulation (Gingras et al. 1999, Labrie et al. 2003, Suzuki et al. 2005). Although diols could be inactivated via glucuroconjugation, the enzymes responsible for this metabolic process (glucuronosyltransferases) have not been characterised in the human mammary gland (Labrie et al. 2003). This observation is in line with the results of the present study, in which no watersoluble androgen metabolites were found. Furthermore, the role of $3 \beta, 5 \alpha$-diol in breast cancer and other hormone-dependent neoplasias deserves further investigation because, in addition to its potent oestrogen-agonistic effects mediated via both subtypes of hER, its bioformation, in contrast to $3 \alpha, 5 \alpha$-diol, is virtually

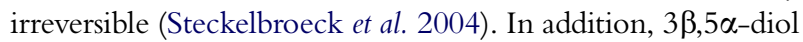
may exert anti-proliferative and apoptotic effects in prostate epithelial cells through its interaction with hER $\beta$ (Weihua et al. 2001, 2002). The preliminary results presented herein demonstrating that $3 \beta, 5 \alpha$-diol and to a lesser extent its $3 \alpha-$ epimer are capable of inducing cell proliferation in cultured MCF-7 cells, in a similar manner to that of oestradiol, yet with lower potency, suggest the involvement of diols in breast cancer progression, however, further studies are required to have a better understanding on the role of diols in this malignancy. The on-going studies in our laboratories indicate that diols bind with low affinity to the human androgen receptor (hAR) and induce very limited hAR-mediated transactivation, particularly the 3 $\alpha, 5 \alpha$-diol (A E Lemus, P Damian-Matsumura, R GarciaBecerra, L Gonzalez, D Orolaz, F Larrea \& G Perez, Unpublished observations). The finasteride-induced inhibition of DHT and diols formation in MCF-7 cells, as demonstrated in this study, may have additional interest, since various locally formed A-ring-reduced metabolites of progesterone (Wiebe et al. 2000, Wiebe \& Muzia 2001, Wiebe \& Lewis 2003) are capable of inducing cell proliferation in human breast cancer, through a novel, non-genomic mechanism (Weiler \& Wiebe 2000). The overall results demonstrated that finasteride inhibits the formation of oestrogenic steroids (diols) generated downstream of DHT, as suggested recently by Ishikawa et al. (2006). In all, this study discloses a distinctive metabolic pathway of androgens in MCF-7 cells leading to a large formation of diols with oestrogen-agonistic activities, providing an insight into the controversial role of testosterone in human breast cancer. The data also demonstrated that pharmacological inhibition of $5 \alpha$-steroid reductases precludes the bioconversion of androgens to non-phenolic metabolites with oestrogen-like effects, opening a new avenue of approach in breast cancer research and treatment. 


\section{Acknowledgements}

Supported partially by Research Macroproject Programme, School of Medicine and PAPIIT (Grant IN202102-3), DGAPA, UNAM; Special Programme of Research, Development and Research Training in Human Reproduction, World Health Organization (Geneva) and the Division of C B S, UAM-I. The expert assistance of Dr Armando Tovar is greatly appreciated. The authors declare that there is no conflict of interest that would prejudice the impartiality of this scientific work.

\section{References}

Adams JB 1998 Adrenal androgens and human breast cancer: a new appraisal. Breast Cancer Research and Treatment 51 183-188.

Ariga N, Moriya T, Suzuki T, Kimura M, Ohuchi N, Satomi S \& Sasano H $200017 \beta$-Hydroxysteroid dehydrogenase type 1 and type 2 in ductal carcinoma in situ and intraductal proliferative lesions of the human breast. Anticancer Research 20 1101-1108.

Aspinall SR, Stamp S, Davison A, Shenton BK \& Lennard TWJ 2004 The proliferative effects of 5 -androstene-3 $\beta, 17 \beta$-diol and $5 \alpha$-dihydrotestosterone on cell cycle analysis and cell proliferation in MCF7, T47D and MDAMB231 breast cancer cell lines. Journal of Steroid Biochemistry and Molecular Biology 88 37-51.

Bonney RC, Reed MJ, Davidson K, Beranek PA \& James VH 1983 The relationship between 17 beta-hydroxysteroid dehydrogenase activity and oestrogen concentrations in human breast tumours and in normal breast tissue. Clinical Endocrinology 19 727-739.

Bradford MM 1976 A rapid and sensitive method for the quantitation of microgram quantities of protein utilizing the principle of protein-dye binding. Analytical Biochemistry 72 248-254.

Brodie AM \& Longcope C 1980 Inhibition of peripheral aromatization by aromatase inhibitors, 4-hydroxy- and 4-acetoxy-androstene-3,17-dione. Endocrinology 106 19-21.

Brodie AM, Schwarzel WC, Shaikh AA \& Brodie HJ 1977 The effect of an aromatase inhibitor, 4-hydroxy-4-androstene-3,17-dione, on estrogendependent processes in reproduction and breast cancer. Endocrinology $\mathbf{1 0 0}$ 1684-1695.

Brueggemeier RW, Hackett JC \& Diaz-Cruz ES 2005 Aromatase inhibitors in the treatment of breast cancer. Endocrine Reviews 26 331-345.

Buzdar AU 2002 New generation aromatase inhibitors - from the advanced to the adjuvant setting. Breast Cancer Research and Treatment 75 S13-S17.

Catherino WH, Jeng MH \& Jordan VC 1993 Norgestrel and gestodene stimulate breast cancer cell growth through an oestrogen receptor mediated mechanism. British Journal of Cancer 67 945-952.

Cheng YC \& Prusoff WH 1973 Relationship between the inhibition constant $\left(K_{\mathrm{i}}\right)$ and the concentration of inhibitor which causes 50 per cent inhibition $\left(\mathrm{I}_{50}\right)$ of an enzymatic reaction. Biochemical Pharmacology 22 3099-3108.

Coombes RC, Goss P, Dowsett M, Gazet JC \& Brodie A 1984 4-Hydroxy androstenedione in treatment of postmenopausal patients with advanced breast cancer. Lancet 2 1237-1239.

Coombes RC, Goss PE, Dowsett M, Hutchinson G, Cunningham D, Jarman M \& Brodie AMH 1987 4-Hydroxyandrostenedione treatment for postmenopausal patients with advanced breast cancer. Steroids 50 245-252.

Costlow ME, Buschow RA \& McGuire WL 1976 Prolactin receptors and androgen-induced regression of 7,12-dimethylbenz(a)anthracene induced mammary carcinoma. Cancer Research 36 3324-3329.

Demers LM 1994 Effects of fadrozole (CGS 16949A) and letrozole (CGS20267) on the inhibition of aromatase activity in breast cancer patients. Breast Cancer Research and Treatment 30 95-102.

García-Becerra R, Borja-Cacho E, Cooney AJ, Jackson KJ, Lemus AE, Pérez-Palacios G \& Larrea F 2002 The intrinsic transcriptional estrogenic activity of a non-phenolic derivative of levonorgestrel is mediated via the estrogen receptor- $\alpha$. Journal of Steroid Biochemistry and Molecular Biology 82 333-341.

Gingras S, Moriggl R, Groner B \& Simard J 1999 Induction of 3ßhydroxysteroid dehydrogenase $/ \Delta^{5}-\Delta^{4}$ isomerase type 1 gene transcription in human breast cancer cell lines and in normal mammary epithelial cells by interleukin-4 and interleukin-13. Molecular Endocrinology 13 66-81.

Girdler F \& Brotherick I 2000 The oestrogen receptors (ER $\alpha$ and ER $\beta$ ) and their role in breast cancer: a review. Breast 9 194-200.

Goss PE 1999 Risks versus benefits in the clinical application of aromatase inhibitors. Endocrine-Related Cancer 6 325-332.

Greeve MA, Allan RK, Harvey JM \& Bentel JM 2004 Inhibition of MCF-7 breast cancer cell proliferation by 5 alpha-dihydrotestosterone; a role for p 21 (Cip1/Waf1). Journal of Molecular Endocrinology 32 793-810.

Hackenberg R, Turgetto I, Filmer A \& Schulz KD 1993 Estrogen and androgen receptor mediated stimulation and inhibition of proliferation by androst-5-ene-3 $\beta, 17 \beta$-diol in human mammary cancer cells. Journal of Steroid Biochemistry and Molecular Biology 46 597-603.

Ishikawa T, Glidewell-Kenney C \& Jameson JL 2006 Aromatase-independent testosterone conversion into estrogenic steroids is inhibited by a $5 \alpha$-reductase inhibitor. Journal of Steroid Biochemistry and Molecular Biology 98 133-138.

Jørgensen L, Brünner N, Spang-Thomsen M, James MR, Clarke R, Dombernowsky P \& Svenstrup B 1997 Steroid metabolism in the hormone dependent MCF-7 human breast carcinoma cell line and its two hormone resistant subpopulations MCF-7/LCC1 and MCF-7/LCC2. Journal of Steroid Biochemistry and Molecular Biology 63 275-281.

Kirschner MA 1979 The role of hormones in the development of human breast cancer. In Breast Cancer 3: Advances in Research and Treatment, Current Topics., New York: Plenum Press. pp 199-229.

Kubli-Garfias C, Vázquez R \& Mendieta J 1998 Austin model 1 study of the effect of carbonyl and hydroxyl functional groups on the electronic structure of androstane. Journal of Molecular Structure (Theochem) 428 189-194.

Kubli-Garfias C, Vázquez R, Cooney AJ \& Larrea F 2002 Ab initio electronic structure of the progestogen norethisterone and its $5 \alpha$-derivatives. Journal of Steroid Biochemistry and Molecular Biology 82 385-391.

Labrie F, Simard J, de Launoit Y, Poulin R, Theriault C, Dumont M, Dauvois S, Martel C \& Li S-M 1992 Androgens and breast cancer. Cancer Detection and Prevention 16 31-38.

Labrie F, Luu-The V, Lin S-X, Labrie C, Simard J, Breton R \& Bélanger A 1997 The key role of $17 \beta$-hydroxysteroid dehydrogenases in sex steroid biology. Steroids 62 148-158.

Labrie F, Bélanger A, Luu-The V, Labrie C, Simard J, Cusan L, Gomez J-L \& Candas B 1998 DHEA and the intracrine formation of androgens and estrogens in peripheral target tissues: its role during aging. Steroids 63 322-328.

Labrie F, Luu-The V, Lin SX, Simard J, Labrie C, El-Alfy M, Pelletier G \& Bélanger A 2000 Intracrinology: role of the family of $17 \beta$-hydroxysteroid dehydrogenases in human physiology and disease. Journal of Molecular Endocrinology 25 1-16.

Labrie F, Luu-The V, Labrie C, Bélanger A, Simard J, Lin S-X \& Pelletier G 2003 Endocrine and intracrine sources of androgens in women: inhibition of breast cancer and other roles of androgens and their precursor dehydroepiandrosterone. Endocrine Reviews 24 152-182.

Larrea F, García-Becerra R, Lemus AE, García GA, Pérez-Palacios G, Jackson KJ, Coleman KM, Dace R, Smith CL \& Cooney AJ 2001 A-ring reduced metabolites of 19-nor synthetic progestins as subtype selective agonists for ER $\alpha$. Endocrinology 142 3791-3799.

Lemus AE, Zaga V, Santillán R, García GA, Grillasca I, Damián-Matsumura P, Jackson KJ, Cooney AJ, Larrea F \& Pérez-Palacios G 2000 The oestrogenic effects of gestodene, a potent contraceptive progestin, are mediated by its A-ring reduced metabolites. Journal of Endocrinology 165 693-702.

Lemus AE, Santillán R, Damián-Matsumura P, García GA, Grillasca I \& Pérez-Palacios G 2001 In vitro metabolism of gestodene in target organs: formation of A-ring reduced derivatives with oestrogenic activity. European Journal of Pharmacology 417 249-256.

Liao DJ \& Dickson RB 2002 Roles of androgens in the development, growth, and carcinogenesis of the mammary gland. Journal of Steroid Biochemistry and Molecular Biology 80 175-189. 
Liao D-ZJ, Cooley GP, Pantazis CG, Hou X \& LiSA 1998 Promotion of estrogeninduced mammary gland carcinogenesis by androgen in the male Noble rat: probable mediation by steroid receptors. Carcinogenesis 19 2173-2180.

Lippman M 1998 Endocrine-responsive cancer. In Williams Textbook of Endocrinology, pp 1675-1692. Eds JD Wilson, DW Foster, HM Kronenberg \& PR Larsen. Philadelphia, PA: W.B. Saunders Company.

Lippman M, Bolan G \& Huff K 1976 The effects of androgens and antiandrogens on hormone responsive human breast cancer in long-term tissue culture. Cancer Research 36 4610-4618.

Lønning PE 2004 Aromatase inhibitors in breast cancer. Endocrine-Related Cancer 11 179-189.

Lopez-Diazguerrero NE, Lopez-Araiza H, Conde-Perezprina JC, Bucio L, Cardenas-Aguayo MC, Ventura JL, Covarrubias L, Gutierrez-Ruiz MC, Zentella A \& Konigsberg M 2006 Bcl-2 protects against oxidative stress while inducing premature senescence. Free Radical Biology and Medicine 40 1161-1169.

Maggiolini M, Donzé O, Jeannin E, Andò S \& Picard D 1999 Adrenal androgens stimulate the proliferation of breast cancer cells as direct activators of estrogen receptor $\alpha$. Cancer Research 59 4864-4869.

Musgrove EA \& Sutherland RL 1994 Cell cycle control by steroid hormones. Seminars in Cancer Biology 5 381-389.

Nicholson RI, Gotting KE, Gee J \& Walker KJ 1988 Actions of oestrogens and antioestrogens on rat mammary gland development: relevance to breast cancer prevention. Journal of Steroid Biochemistry 30 95-103.

Pasqualini JR \& Chetrite G 1996 Activity, regulation and expression of sulfatase, sulfotransferase, and $17 \beta$-hydroxysteroid dehydrogenase in breast cancer. In Hormone-Dependent Cancer, pp 25-80. Eds JR Pasqualini \& BS Katzenellenbogen. New York, NY, USA: Marcel Dekker, Inc.

Pike MC \& Spicer DV 1991 Endogenous estrogen and progesterone as the major determinants of breast cancer risk: prospects for control by "natural" and "technological" means. In Hormonal Carcinogenesis, pp 209-216. Eds JJ Li, S Nandi \& SA Li. New York, NY, USA: Springer-Verlag.

Pike MC, Spicer DV, Dahmoush L \& Press MF 1993 Estrogens, progestogens, normal breast cell proliferation, and breast cancer risk. Epidemiologic Reviews 15 17-35.

Poulin R, Baker D \& Labrie F 1988 Androgens inhibit basal and estrogeninduced cell proliferation in the ZR-75-1 human breast cancer cell line. Breast Cancer Research and Treatment 12 213-225.

Ragaz J 1999 Status of aromatase inhibitors in relation to other breast cancer treatment modalities. Endocrine-Related Cancer 6 277-291.

Reel JR, Humphrey RR, Shih Y-H, Windsor BL, Sakowski R, Creger PL \& Edgren RA 1979 Competitive progesterone antagonists: receptor binding and biological activity of testosterone and 19-nortestosterone derivatives. Fertility and Sterility 31 552-561.

Roy R, Dauvois S, Labrie F \& Bélanger A 1992 Estrogen-stimulated glucuronidation of dihydrotestosterone in MCF-7 human breast cancer cells. Journal of Steroid Biochemistry and Molecular Biology 41 579-582.

Russell DW \& Wilson JD 1994 Steroid $5 \boldsymbol{\alpha}$-reductase: two genes/two enzymes. Annual Review of Biochemistry 63 25-61.

Santen RJ, Manni A, Harvey H \& Redmond C 1990 Endocrine treatment of breast cancer in women. Endocrine Reviews 11 221-265.

Santillán R, Pérez-Palacios G, Reyes M, Damián-Matsumura P, García GA, Grillasca I \& Lemus AE 2001 Assessment of the oestrogenic activity of the contraceptive progestin levonorgestrel and its non-phenolic metabolites. European Journal of Pharmacology 427 167-174.

Sasano H, Frost AR, Saitoh R, Harada N, Poutanen M, Vihko R, Bulun SE, Silverberg SG \& Nagura H 1996 Aromatase and 17 $\beta$-hydroxysteroid dehydrogenase type 1 in human breast carcinoma. Journal of Clinical Endocrinology and Metabolism 81 4042-4046.

Sasano H, Sato S, Ito K, Yajima A, Nakamura J, Yoshihama M, Ariga K, Anderson TJ \& Miller WR 1999 Effects of aromatase inhibitors on the pathobiology of human breast, endometrial and ovarian carcinoma. Endocrine-Related Cancer 6 197-204.

Schoonen WGEJ, Joosten JWH \& Kloosterboer HJ 1995a Effects of two classes of progestagens, pregnane and 19-nortestosterone derivatives, on cell growth of human breast tumor cells: I. MCF-7 cell lines. Journal of Steroid Biochemistry and Molecular Biology 55 423-437.

Schoonen WGEJ, Joosten JWH \& Kloosterboer HJ $1995 b$ Effects of two classes of progestagens, pregnane and 19-nortestosterone derivatives, on cell growth of human breast tumor cells: II, T47D cell lines. Journal of Steroid Biochemistry and Molecular Biology 55 439-444.

Smith JA \& King RJ 1972 Effects of steroids on growth of an androgendependent mouse mammary carcinoma in cell culture. Experimental Cell Research 73 351-359.

Smith CL, Conneely OM \& O'Malley BW 1993 Modulation of the ligandindependent activation of the human estrogen receptor by hormone and antihormone. PNAS 90 6120-6124.

Somboonporn W \& Davis SR 2004 Testosterone effects on the breast: implications for testosterone therapy for women. Endocrine Reviews 25 374-388.

Sonne-Hansen K \& Lykkesfeldt AE 2005 Endogenous aromatization of testosterone results in growth stimulation of the human MCF-7 breast cancer cell line. Journal of Steroid Biochemistry and Molecular Biology 93 25-34.

Steckelbroeck S, Jin Y, Gopishetty S, Oyesanmi B \& Penning TM 2004 Human cytosolic $3 \alpha$-hydroxysteroid dehydrogenases of the aldo-keto reductase superfamily display significant $3 \beta$-hydroxysteroid dehydrogenase activity. Journal of Biological Chemistry 279 10784-10795.

Suzuki T, Moriya T, Ariga N, Kaneko C, Kanazawa M \& Sasano H 2000 17ßHydroxysteroid dehydrogenase type 1 and type 2 in human breast carcinoma: a correlation to clinicopathological parameters. British Journal of Cancer 82 518-523.

Suzuki T, Darnel AD, Akahira J-I, Ariga N, Ogawa S, Kaneko C, Takeyama J, Moriya T \& Sasano H $20015 \alpha$-Reductases in human breast carcinoma: possible modulator of in situ androgenic actions. Journal of Clinical Endocrinology and Metabolism 86 2250-2257.

Suzuki T, Miki Y, Nakamura Y, Moriya T, Ito K, Ohuchi N \& Sasano H 2005 Sex steroid producing enzymes in human breast cancer. Endocrine-Related Cancer 12 701-720.

Szelei J, Jimenez J, Soto AM, Luizzi MF \& Sonnenschein C 1997 Androgeninduced inhibition of proliferation in human breast cancer MCF7 cells transfected with androgen receptor. Endocrinology 138 1406-1412.

Weihua Z, Mäkelä S, Andersson LC, Salmi S, Saji S, Webster JI, Jensen EV, Nilsson S, Warner M \& Gustafsson J-Å 2001 A role for estrogen receptor $\beta$ in the regulation of growth of the ventral prostate. PNAS $\mathbf{9 8} 6330-6335$.

Weihua Z, Lathe R, Warner M \& Gustafsson J-A 2002 An endocrine pathway in the prostate, ER $\beta, A R, 5 \alpha$-androstane- $3 \beta, 17 \beta$-diol, and CYP7B1, regulates prostate growth. PNAS 99 13589-13594.

Weiler PJ \& Wiebe JP 2000 Plasma membrane receptors for the cancerregulating progesterone metabolites, $5 \alpha$-pregnane-3,20-dione and $3 \alpha-$ hydroxy-4-pregnen-20-one in MCF-7 breast cancer cells. Biochemical and Biophysical Research Communications 272 731-737.

Wiebe JP \& Muzia D 2001 The endogenous progesterone metabolite, $5 \alpha$ pregnane-3,20-dione, decreases cell-substrate attachment, adhesion plaques, vinculin expression, and polymerized F-actin in MCF- 7 breast cancer cells. Endocrine 16 7-14.

Wiebe JP \& Lewis MJ 2003 Activity and expression of progesterone metabolizing $5 \alpha$-reductase, $20 \alpha$-hydroxysteroid oxidoreductase and $3 \alpha(\beta)$-hydroxysteroid oxidoreductases in tumorigenic (MCF-7, MDA-MB-231, T-47D) and nontumorigenic (MCF-10A) human breast cancer cells. BMC Cancer 3 1-15.

Wiebe JP, Muzia D, Hu J, Szwajcer D, Hill SA \& Seachrist JL 2000 The 4-pregnene and $5 \alpha$-pregnane progesterone metabolites formed in nontumorous and tumorous breast tissue have opposite effects on breast cell proliferation and adhesion. Cancer Research 60 936-943.

Wing LY, Garrett WM \& Brodie AM 1985 Effects of aromatase inhibitors, aminoglutethimide, and 4-hydroxyandrostenedione on cyclic rats and rats with 7,12-dimethylbenz(a)anthraceneinduced mammary tumors. Cancer Research 45 2425-2428.

Xie B, Tsao SW \& Wong YC 1999 Sex hormone-induced mammary carcinogenesis in female Noble rats: the role of androgens. Carcinogenesis $\mathbf{2 0}$ 1597-1606.

Zhou J, Ng S, Adesanya-Famuiya O, Anderson K \& Bondy CA 2000 Testosterone inhibits estrogen-induced mammary epithelial proliferation and suppresses estrogen receptor expression. FASEB Journal 14 1725-1730.

Received in final form 2 May 2006

Accepted 15 May 2006

Made available online as an Accepted Preprint 9 June 2006 